\title{
Remittances and the Brain Drain Revisited: The microdata show that more educated migrants remit more
}

Albert Bollard, David McKenzie, Melanie Morten, Hillel Rapoport

CID Working Paper No. 190

December 2009

(C) Copyright 2009 Albert Bollard, David McKenzie, Melanie Morten, Hillel Rapoport and the President and Fellows of Harvard College

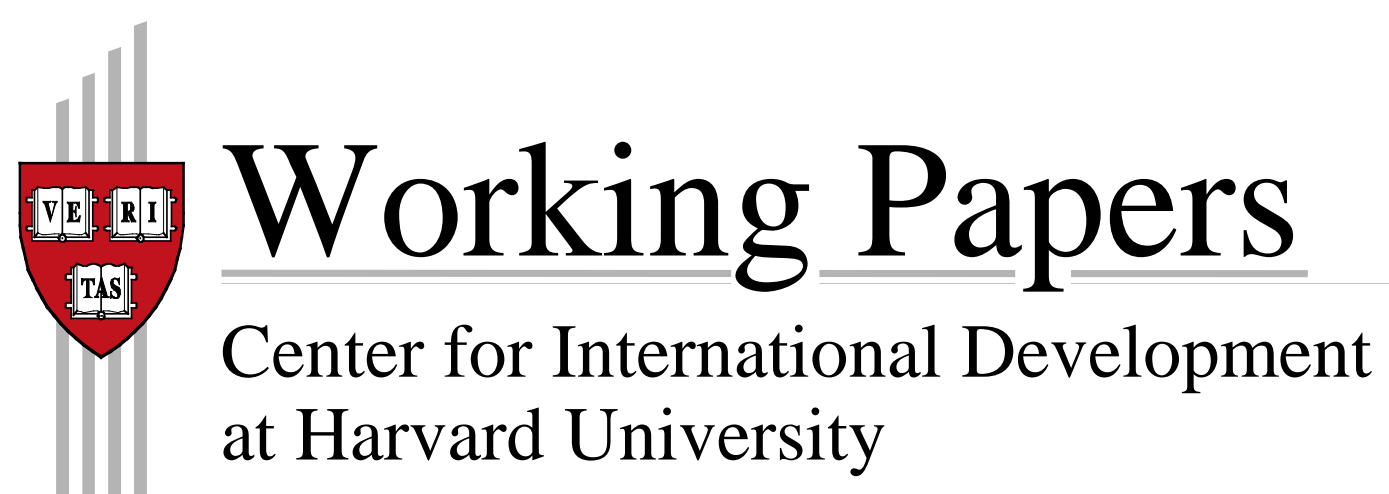




\title{
Remittances and the Brain Drain Revisited:
}

\section{The microdata show that more educated migrants remit more ${ }^{\#}$}

\author{
Albert Bollard, Stanford University \\ David McKenzie, World Bank, BREAD, IZA and CReAM \\ Melanie Morten, Yale University \\ Hillel Rapoport, Bar-Ilan University, EQUIPPE and CID, Harvard University
}

\begin{abstract}
Two of the most salient trends surrounding the issue of migration and development over the last two decades are the large rise in remittances, and an increased flow of skilled migration. However, recent literature based on cross-country regressions has claimed that more educated migrants remit less, leading to concerns that further increases in skilled migration will hamper remittance growth. We revisit the relationship between education and remitting behavior using microdata from surveys of immigrants in eleven major destination countries. The data show a mixed pattern between education and the likelihood of remitting, and a strong positive relationship between education and the amount remitted conditional on remitting. Combining these intensive and extensive margins gives an overall positive effect of education on the amount remitted. The microdata then allow investigation as to why the more educated remit more. We find the higher income earned by migrants, rather than characteristics of their family situations explains much of the higher remittances.
\end{abstract}

Keywords: Remittances, Migration, Brain Drain, Education.

JEL Codes: O15, F22, J61.

\footnotetext{
\# We are grateful for funding for this project from the Agence Française de Développement (AFD). We thank the various individuals and organizations who graciously allowed us to use their surveys of immigrants and Michael Clemens for helpful comments. All opinions are of course our own and do not represent those of AFD, or of the World Bank.
} 


\section{Introduction}

Two of the most salient trends surrounding the issue of migration and development over the last two decades are the large rise in remittances, and an increased flow of skilled migration. Officially recorded remittances to developing countries have more than tripled over the last decade, rising from US\$85 billion in 2000 to US\$305 billion in 2008 (World Bank, 2008, 2009). The number of highly educated emigrants from developing countries residing in the OECD doubled between 1990 and 2000 (Docquier and Marfouk, 2005) and is likely to have grown since as developed countries have increasingly pursued skill-selective immigration policies.

However, despite this positive association at the global level between rising remittances and rising high-skilled emigration, there are concerns that the increasingly skill-selective nature of immigration policies may hamper the rise in remittances, due to a belief that more educated individuals may remit less. This belief is accepted as fact by many: for example, the OECD (2007, p. 11) writes “low-skilled migrants tend to send more money home”. The main empirical evidence to support this across a range of countries comes from two recent papers (Faini, 2007 and Niimi, et al. 2008) which use cross-country macroeconomic approaches to claim that the highly skilled (defined as those with tertiary education) remit less.

Yet there are many reasons not to believe these cross-country estimates nor to consider them useful for policy. Both studies relate the amount of remittances received at a country level to the share of migrants with tertiary education, at best telling us whether countries which send a larger share of highly skilled migrants receive less or more remittances than countries which send relatively fewer skilled migrants. ${ }^{1}$ This does not answer the factual question "do more educated individuals remit more or less?” There are a host of differences across countries which could cause a spurious relationship between remittances and skill level across countries. For example, if poverty is a constraint to both migration and education, we may find richer developing countries being able to send more migrants (yielding more remittances) and that the migrants from these countries also have more schooling. In addition to this, by focusing on the relative share of migrants who are skilled rather than the absolute number, these papers are not

\footnotetext{
${ }^{1}$ A further concern is that the macroeconomic data on remittances covers only remittances through formal sources, and the share of total remittances which are thus reported by country will differ, and may differ in a way which is correlated with their share of tertiary-educated migrants if migrants differ in their propensity to use formal remittance channels according to education level.
} 
informative as to what one should expect to happen to remittances as destination countries continue to adopt more skill-intensive migration policies.

This paper revisits the relationship between remittances and the educational level of migrants using microdata, allowing us to compute the association between an individual's education level and remitting behavior. An intensive effort allows us to put together the most comprehensive micro-level database on remitting behavior currently available, comprising of data on 33,000 immigrants from developing countries from 14 surveys in 11 OECD destination countries. Using this new dataset, we begin by establishing the factual relationship between the propensity to remit and education. ${ }^{2}$ With microdata we can ask whether or not more educated individuals are more or less likely to remit (the extensive margin), and whether they send more or less remittances if they do remit (the intensive margin). We find a mixed association between education and remittances at the extensive margin, and a strong positive relationship at the intensive margin. Combining the two, the fact is that more educated migrants do remit significantly more - migrants with a university degree remit \$300 more yearly than migrants without a university degree, where the mean annual remittance over the entire sample is $\$ 730$.

Theory provides reasons why the relationship between the amount remitted and education could be positive or negative. The more educated are likely to earn more, be repaying education loans, have more access to financial institutions, but also have their family members accompanying them, have wealthier families with less need for remittances, and have presumably less intention of returning to their home country. Using other variables from the microdata we investigate which channels seem to explain the differential remitting behavior of the more educated. We find remitting behavior to have the associations with these different individual characteristics that are predicted by theory, and that the higher income of more educated migrants appears to be the main reason they remit more.

The remainder of the paper is set out as follows. Section 2 summarizes several theories of remitting behavior and the predictions they give for the relationship between education and

\footnotetext{
${ }^{2}$ We do not attempt to estimate the causal impact of education on remittances. From a policy perspective, the interest is in whether migration policies which shift the education composition of migrants affect remittances, not on whether education policies to change how much education individuals have affects remittances. Moreover, we lack convincing instruments to identify the latter.
} 
remittances. Section 3 then describes our dataset of immigrant surveys with remittances. Section 4 provides results, and Section 5 concludes.

\section{Theoretical background}

Theoretically there are several reasons to believe that there will be differences between the remitting patterns of highly-skilled emigrants and less-skilled emigrants. On one hand there are several factors which would tend to lead highly skilled migrants to be more likely to remit and/or send a larger amount of remittances. First, highly skilled individuals are likely to earn more as migrants, increasing the potential amount they can remit. Second, their education may have been funded by family members in the home country, with remittances providing a repayment of this family investment. Third, skilled migrants are less likely to be illegal migrants, and more likely to have bank accounts, lowering the financial transactions costs of remitting. However, on the other hand there are several factors which may lead highly skilled migrants to be less likely to remit or to remit less. First, highly skilled migrants may be more likely to migrate with their entire household, so not have to send remittances in order to share their earnings abroad with other household members. Second, they may come from richer households, who have less need for remittances to alleviate liquidity constraints. Third, they may have less intention of ever returning to their home country, reducing the role of remittances as a way of maintaining prestige and ties to the home community. A priori then, it is not clear which direction will dominate, and thus whether the highly skilled will remit more or less on average.

One key point to note from all of these theoretical channels is that education doesn't enter directly as a determinant of remittances; rather, education is associated with other things that affect remitting behavior. Before we turn to the empirical analysis, it may therefore be useful to summarize the existing literature and clarify the theoretical relationship between education and remittances, and the implied testable predictions regarding education. In this section we present a brief summary of the theoretical literature based on Rapoport and Docquier (2006) and focus the discussion on the role of education.

Thanks to the new economics of labor migration (Stark, 1991), migration is now recognized as an informal familial arrangement, with benefits in the realms of mutual insurance, consumption smoothing, and intergenerational financing of investments, including education. Remittances are an integral part of such implicit arrangements and can be seen as combining an 
altruistic component, a repayment-of-loans component, an insurance component, an inheritance component, and exchanges of a variety of services. In the discussions below we select three of these motives - altruism, exchange, and investment - both for their general empirical relevance and for the fact that they are the ones through which education is most likely to affect remittances.

\subsection{Altruism.}

Building on Rapoport and Docquier (2006) and Niimi et al. (2008), we write the migrant's utility function as:

$U_{M}=\left(1-\gamma_{N}-\gamma_{S}\right) V\left(C_{M}\right)+\gamma_{N} V\left(C_{N}\right)+\gamma_{S} V\left(C_{S}\right), V^{\prime}>0$ and $V^{\prime \prime}<0$,

where:

$C_{M}$ is the migrant's consumption level,

$C_{N}$ is the consumption of the family members in the host country (North),

$C_{S}$ is the consumption level of the family members in the home country (South)

$\gamma_{N}=\beta_{N} f_{N}$ and $\gamma_{S}=\beta_{S}\left(1-f_{N}\right)$, with $1>\beta_{N}>\beta_{S}$ to denote that the migrant prefers to have his relatives close to him, ${ }^{3}$ and

$f_{N}$ is the fraction of the family (of total size normalized to unity) who lives in the North.

With $V()=.\ln ($.$) and noting that C_{M}=y_{M}-T_{N}-T_{S}, C_{N}=y_{N}+T_{N}$ and $C_{S}=y_{S}+T_{S}$, the migrant's remittance decision may be written as:

$$
\underset{T_{N}, T_{S}}{\operatorname{Max}} U_{M}=\left(1-\gamma_{N}-\gamma_{S}\right) \ln \left(y_{M}-T_{N}-T_{S}\right)+\gamma_{N} \ln \left(y_{N}+T_{N}\right)+\gamma_{S} \ln \left(y_{S}+T_{S}\right)
$$

From the first order conditions we get the optimal levels of transfers to the accompanying family and of remittances:

$T_{N}^{*}=\gamma_{N} y_{M}-y_{N}\left(1-\gamma_{N}-\gamma_{S}\right)$

and

$T_{S}^{*}=\gamma_{S} y_{M}-y_{S}\left(1-\gamma_{N}-\gamma_{S}\right)$.

\footnotetext{
${ }^{3}$ Another interpretation is that the people who live with the migrant are closer relatives -- spouse, children -- than those left behind and therefore receive a higher altruistic weight in the migrant's utility function.
} 
We may now ask: how do educated migrants differ from non-educated migrants? First, they earn more $\left(y_{M}^{e}>y_{M}^{n e}\right)$, which all else equal should induce more remittances as $\frac{\partial T_{S}}{\partial y_{M}}=\gamma_{S}>0$; and second, the conventional wisdom is they tend to have more family members with them as they have a higher propensity to move with their immediate family $\left(f_{N}^{e}>f_{N}^{n e}\right)$; all else equal this should act to decrease remittances as:

$$
\frac{\partial T_{S}^{*}}{\partial f_{n}}=\frac{\partial T_{S}^{*}}{\partial \gamma_{N}} \cdot \frac{\partial \gamma_{N}}{\partial f_{N}}+\frac{\partial T_{S}^{*}}{\partial \gamma_{S}} \cdot \frac{\partial \gamma_{S}}{\partial f_{N}}=y_{S}\left(\beta_{N}-\beta_{S}\right)-\beta_{S} y_{M}<0.4
$$

From the perspective of this paper, it is interesting to note that education does not enter directly in the model at this stage: it is assumed exogenous and does not have any impact beyond its effect on the migrants' income (it is also assumed preferences are independent of education). More importantly, the reason why more educated migrants may remit less in an altruistic model is that they are more likely to bring their families with them. This raises in turn two important issues. First, from a social welfare viewpoint, this begs the question of why we should care about the level of remittances: if remittances are lower when more educated individuals migrate because families stay together, isn't this a welfare gain? Second, from a methodological perspective, this theory suggests that the location/composition of the family (i.e., which fraction of the family is accompanying the migrant and which fraction is staying in the home country) is jointly determined with remittances. This makes it difficult to estimate the causal impact of family composition on remittances. Instead, we will merely ask whether differences in remitting patterns by education level disappear when we condition on family composition. Empirically we will also see that while less-educated migrants do have more relatives in the home country, they also have larger household sizes and also have larger numbers of relatives with them in the destination country.

${ }^{4}$ To prove this we must first note that the condition for a negative sign is $\frac{y_{M}}{y_{S}}>\frac{\beta_{N}}{\beta_{S}}-1$ while the condition for having positive transfers is $\frac{y_{M}}{y_{S}}>\frac{1-\gamma_{N}}{\gamma_{S}}-1$. It is easy to see that the latter condition implies the former as long as $\beta<1$. 


\subsection{Exchange and investment motives.}

There are many situations of pareto-improving exchanges where remittances "buy" various types of services such as taking care of the migrant's assets (e.g., land, cattle) or relatives (children, elderly parents) at home. Such motivations are generally the sign of a temporary migration, and signal the migrants' intention to return. In such exchanges, there is a participation constraint determined by each partner's external options, with the exact division of the pie (or surplus) to be shared depending on their bargaining power. How does education interact with such exchange motives? Two directions emerge from the short discussion above: through the effect of education on intentions to return, on the one hand, and through its effect on threat points and bargaining powers, on the other hand.

The conventional wisdom is that migrants with higher education have lower intentions (and propensities) to return than migrants with low education (see Faini, 2007), either because they tend to be better integrated, or can obtain permanent resident status more easily. Should this be the case, educated migrants should transfer less for an exchange motive, reflecting their lower propensities to return. ${ }^{5}$ What about bargaining powers? As is well known, exchange models allow for different possible contractual arrangements reflecting the parties' outside options and bargaining powers (see, e.g., Cox, 1987, Cox et al., 1998). This has two complementary implications for the role of education as a determinant of remittances in an exchange model. First, to the extent that education is associated with higher income, this is likely to increase the migrants' willingness to pay and lead to higher remittances; and second, to the extent that educated migrants come from more affluent families, this is likely to increase the receiving household bargaining power and also lead to higher remittances. ${ }^{6}$ On the whole, an exchange motive therefore predicts education will have an ambiguous effect on remittances, with the sign of the effect depending on whether return intentions or bargaining issues matter more in determining remittance behavior.

The investment motive may be seen as a particular exchange of services in a context of imperfect credit markets. In such a context indeed, remittances may be seen as part of an implicit

\footnotetext{
${ }^{5}$ Again, as we shall see, this conventional wisdom is not supported by the data, meaning that exchange motives are equally relevant for educated and less educated migrants as far as return intentions are concerned.

${ }^{6}$ To save place we did not include the formal development of these points, which is available from the authors upon request.
} 
migration contract between the migrant and his or her family, allowing the family access to higher (investment motive) and/or less volatile (insurance motive) income. Since the insurance motive does not in theory give rise to clear differences in transfer behavior between educated and less educated migrants, we will focus here on the investment motive. The amount of investment financed by the family may include physical (e.g., transportation) and informational migration costs, as well as education expenditures, and the repayment of this implicit loan through remittances is obviously expected to depend on the magnitude of the loan. Hence, the investment motive clearly predicts that all else equal, more educated migrants should remit more to compensate the family for the additional education expenditures incurred.

\subsection{Summary of predictions}

To summarize, both the altruistic and the exchange/investment motives for remittances give unclear theoretical predictions as to whether more educated migrants should remit more or less. Once the migrants' incomes are controlled for, their education level should not play any role under the altruistic hypothesis (assuming preferences are exogenous to education) except for its effect on the spatial distribution of the family. As already noted, the conventional wisdom here is that the highly educated tend to move with their closer family, which will affect remittances negatively. Similarly, education is expected to impact negatively on remittances under the exchange hypothesis as educated migrants have lower propensities to return. While this is likely to affect mainly the likelihood of remittances (i.e., to affect them at the extensive margin), bargaining mechanisms play in the other direction and should translate into higher remittances for those who remit (i.e., at the intensive margin), with the sign of the total expected effect being theoretically uncertain. Finally, education is likely to have a clear positive impact on remittances under the investment hypothesis.

Given the discussions above and the fact that the descriptive statistics of our sample do not support the conjecture that more educated migrants have a substantially higher propensity to move with their family or a substantially lower propensity to return, we should expect the other forces at work to dominate and give rise to more remittances originating from migrants with more education; which is indeed what we find. 


\section{Data}

An intensive effort allows us to put together the most comprehensive micro-level database on remitting behavior currently available, comprising of data on 33,000 immigrants from developing countries from 14 surveys in 11 OECD destination countries. These countries were the destination for $79 \%$ of all global migrants to OECD countries in 2000 (Docquier and Marfouk, 2005). The focus on destination country data sources allows us to look directly at the relationship between education and remittance sending behavior by analyzing the decision to remit by the migrants themselves. It also enables us to capture the remittance behavior of individuals who emigrate with their entire household, whereas using household surveys from the remittance-recipient countries would typically miss such individuals. Since more-educated individuals are believed to be more likely to emigrate with their entire household than lesseducated individuals (Faini, 2007), it is apparent that using surveys from migrant-sending countries will not be appropriate for examining the relationship between remittances and education.

The majority of the empirical literature on immigrants has used data from either Census or labor force surveys. However, neither contains information on remittances. Instead, we must use special purpose surveys of immigrants. We have pulled together all of the publicly available datasets we are aware of, ${ }^{7}$ along with six additional surveys that are not publicly available, but which other researchers were generous enough to share. Table 1 provides an overview of our comprehensive database of migrants, outlining a summary of the datasets, sample population, and survey methodology. Our database covers a wide range of populations, covering both nationally representative surveys such as the New Immigrant Survey (NIS) in the United States (drawn from green card recipients) and the Spanish National Survey of Immigrants (ENI), which draws on a neighborhood sampling frame, as well as surveys which focus on specific migrant communities within the recipient country, such as the Black/Minority Ethnic Survey (BME) in the United Kingdom and the Belgium International Remittance Senders Household Survey, which surveyed immigrants from Senegal, Nigeria and the Congo. In all cases, we keep only migrants who were born in developing countries. ${ }^{8}$

\footnotetext{
${ }^{7}$ Exceptions include longitudinal surveys of immigrants from Canada and New Zealand, which can only be accessed through datalabs in these countries, and so are not included here.

${ }^{8}$ High Income countries are defined based on the World Bank Country Classification Code, April 2009.
} 
For each country dataset we construct comparable covariates to measure household income, remittance behavior, family composition, and demographic characteristics. Remittances are typically measured at the household level, not the individual level. Our level of analysis is therefore the household and we define variables at this level whenever possible, for example by taking the highest level of schooling achieved by any migrant adult in the household. All financial values are reported in constant 2003 US\$. In addition, we drop any observations where reported annual remittances are more than twice annual household income. We always use sample weights provided with the data. To pool the data, we post-stratify by country of birth and education so that the combined weighted observations match the distribution of developing country migrants to all OECD countries in the year 2000 (Docquier and Marfouk, 2005). See the data appendix for further details.

Table 2 presents summary statistics for each country survey and the pooled samples of all destination countries. Overall, 37\% of the migrants in our database have completed a university degree, ranging from $4 \%$ in the Spanish NIDI survey to 59\% in the Belgium IRSHS survey. The remainder of the table summarizes the covariates by the maximum educational attainment of all adult migrants in the household. The significance stars indicate that the mean of the variable is statistically different between university-educated and non-university educated households. Altogether, including both the extensive and intensive margins, more educated migrants send home an average of $\$ 874$ annually, compared with $\$ 650$ for less educated migrants. There are two opposing effects: a negative effect of education on the extensive margin, and a positive effect of education on the intensive margin. At the extensive margin, migrants with a university degree are less likely to remit anything than those without a degree: 32\% of low-skilled migrants send any money home, compared with $27 \%$ of university-educated migrants. However, conditional on remitting (the intensive margin), highly educated migrants send more money back, sending about 9\% more than less-educated migrants.

Table 2 also shows how characteristics which can affect remittance behavior differ between less- and more-educated migrants. Firstly, more skilled migrants are both more likely to live in a household where adults are working, as well as have a higher household income, than low skilled migrants. However, contrary to conventional wisdom, the household composition of the two types of migrants is not so different: on average, only $6 \%$ of low skilled migrants have a spouse outside the country, compared with 3\% of high skilled migrants. Low skilled migrants are 
significantly less likely to be married than high skilled migrants (74\% against 63\%). Low skilled migrants do have more children (an average of 2.03, versus 1.37 for high skilled migrants), as well as more children living outside the destination country (on average, 0.50 children compared to 0.25 ), than high skilled migrants. However, low skilled migrants also have more family inside the recipient country than high skill migrants: the average household size for low skilled migrants is 3.76 people, statistically different from a mean household size of 3.36 people for high skilled migrants. Another piece of conventional wisdom, that more educated people are less likely to return home, is also not supported by our data. In fact, more educated migrants have spent less time abroad than less educated migrants (a mean of 10.3 years for low-skill migrants, compared to a mean of 8.4 years for high-skill migrants), and the reported plans to return home are very similar between the two groups: $9 \%$ of skilled migrants report planning to return home, compared to $11 \%$ of low-skilled migrants.

The simple comparison of means in Table 2 shows differences in remittance behavior by education status. However, these comparisons of means only allow us to say that more-educated developing country emigrants remit more than less-educated developing country emigrants. This risks confounding differences in remittance behavior among migrants from different countries with differences in remittance behavior by education level. So we next carry out regressions which enable us to establish whether more educated households from the average migrantsending developing country remit more or less than less educated households from the same country.

\section{Results}

Table 3 presents the main results. The top panel measures education by university degree and the bottom panel by years of schooling. In each panel, we regress three different remittance measures on education: total remittances (both extensive and intensive margins), an indicator for having remitted in the previous year (extensive margin) and log total remittances conditional on remitting (intensive margin). All regressions include country of birth fixed effects and dataset fixed effects.

The key result in Table 3 is that more educated migrants remit more. The coefficient in the top-right shows that in the pooled sample migrants with a university degree remit \$298 more 
per year than non-university educated migrants, when the mean annual remittance for all migrants of $\$ 734$. This overall effect is composed of a negative (statistically insignificant) effect at the extensive margin, and a highly significant positive effect on the intensive margin. The results are consistent when the second measure of education, years of schooling, is considered.

When we consider the individual country results, we see mixed results at the extensive margin, with education significantly positively associated with the likelihood of remitting in two surveys (the USA New Immigrant Survey and Survey of Brazilians and Peruvians in Japan), significantly negatively associated with this likelihood in three surveys (the USA Pew survey and both Spanish surveys), and no significant relationship in the other six surveys, with three positive and three negative point estimates. One general observation is that a more negative relationship appears in surveys which focus on sampling migrants through community-sampling methods, such as the NiDi surveys which go to agglomeration points where migrants cluster, and the Pew Hispanic surveys which randomly dial phone numbers in high Hispanic areas. One might expect the educated migrants who live in such areas (and who take the time to respond to phone or on the street surveys) to perhaps be less successful than educated migrants who live in more integrated neighborhoods and thus who wouldn't be picked up in these surveys.

In contrast, at the intensive margin the individual survey results show a positive relationship in 10 out of 12 surveys, five of which are statistically significant, and negative and insignificant relationships in the remaining two surveys. Thus it is not surprising that when we pool the data we find a strong positive association at the intensive level, and that this outweighs the small negative and insignificant relationship when it comes to the total effect.

This point is made graphically by Figure 1, which plots the non-parametric relationship between total remittances and years of schooling, after linearly controlling for dataset fixed effects using a partial linear model (Robinson 1988), together with a 95\% confidence interval, on a log scale. The vertical lines demarcate the quartiles of the distribution of years of schooling. Average remittances steadily increase from around \$500 in the lowest education quartile to close to $\$ 1000$ for those with university degrees. Moreover, the positive association is most strongly increasing for those with post-secondary education, which shows that not only do those with some university remit more than those without, but that postgraduates are remitting more than those with only a couple of years of university. 
Next we use this microdata to explore some of the channels through which education might influence remittances. Section 2 set out a number of explanations as to why remitting behavior may vary with education. We observe proxies for many of these. In particular, we can control for differences in household income and work status, differences in household demographics and the presence of family abroad, differences in time spent abroad, differences in legality status, and differences in intentions to return home.

Table 4 shows the results of adding this full set of variables to the pooled model, using years of education as the measure of educational attainment. These channels are operating as theory would predict. Households with more income and where adults work more are more likely to remit: households where a migrant member is working send \$345 more annually, and a $10 \%$ increase in income will cause approximately an extra $\$ 38$ to be remitted annually. As expected, family composition variables are also strongly significant both overall and for the extensive and intensive margins: a spouse outside the country is associated with a colossal additional \$1120 remitted each year, approximately one and a half times the mean annual remittance over all migrants. Each child and parent living outside the destination country are associated with an additional \$340 and \$180 remitted annually respectively. Residing in the destination country legally is associated with an additional \$400 annually, showing no evidence that legal migrants lose their desire to remain in contact with their country of origin. Migrants who plan to move back home also remit significantly more, but this effect is primarily through the extensive margin rather than the intensive margin.

We then ask which channels account for the association between education and remittance behavior. Tables 5, 6 and 7 report how the coefficient on education in an OLS regression changes as controls are added for total remittances, the intensive margin, and the extensive margin respectively. The top panel in each table measures education by a university degree and the bottom panel uses years of schooling. In each case we begin by showing the baseline education coefficient from Table 3, which comes from regressing remittances only on education and country of birth and dataset fixed effects. The next row shows how this coefficient changes when we add controls for income and work status. The third row instead adds controls for family composition (household size, dummy if married, dummy if spouse is outside the country, number of children, number of children outside the country, number of parents and 
number of parents outside the country). The final row adds all the controls from Table 4: both the income and family controls, as well as legal status, time spent abroad, and intent to return home.

We find that remittance behavior is primarily accounted for by income, and not by differences in family composition. The baseline result for total remittances from Table 3, controlling only for country of birth and dataset fixed effects, is that migrants with a university degree remit \$300 more than migrants without a university degree. Controlling for the full set of covariates (the 'all' row) reduces the coefficient on university degree by two-thirds, and it becomes statistically insignificant. The third row adds just the family composition variables to the baseline specification. The main hypothesis for why less skilled migrants remit more is because they are more likely to have family members outside the country. Therefore, we would expect that controlling only for this (but not for other variables such as income) would increase the coefficient on education, but we find the opposite - the coefficient on education reduces to $\$ 230$ from $\$ 300$, and remains statistically significant. This casts doubt on the idea that low skilled migrants remit more because of their family composition. One explanation for this is the earlier observation that low skilled migrants are not only likely to have more family abroad, but they are also likely to live in households with more people in the host country. The second row of the table adds just income variables (a dummy for working and log income) to the baseline specification. The coefficient on university degree is cut by more than half, and is no longer statistically significant. This suggests that the income effect is a key channel through which education affects remittances: in short, more educated people send back more money simply because they have higher incomes.

Although we find that education is insignificant once we control for income in the pooled sample, this masks heterogeneity in the individual surveys. For example, the education coefficient remains statistically significant even after controlling for all available covariates for three datasets: the Spanish ENI survey, the USA Pew dataset, and the USA NIS survey. There are several reasons why the education coefficient might remain significant in some datasets and not others that we are not able to examine with our dataset. One key variable we cannot control for is the socioeconomic status of the family in the home country. More educated individuals might come from better-off families, and therefore not need to send back as much money. This 
could explain the negative coefficient in the ENI and the Pew dataset. ${ }^{9}$ Or more educated individuals might have fewer ties to their home country. We have attempted to control for this using time spent away from the home country, and desire to return home, but this may not fully capture the strength of the ties. We also do not have data on whether migrants are repaying family for loans, for example for education. One additional key issue is that our use of crosssection data does not yield any information about economic shocks that affect either the migrant or the family.

Table 6 examines the extensive margin. More educated migrants are less likely to remit anything in the baseline specification, but this is not statistically significant. We find that the negative effect of education on the decision to remit anything is strengthened by the inclusion of different sets of covariates. The coefficient on education (measured by university degree) is negative and significant once any covariates are included. The alternative measure of education, years of schooling, is not statistically significant. The intensive margin result (Table 7), that once the decision is made to remit, more educated migrants remit more, again appears to be driven by the income effect. Adding only family variables to the baseline specification reduces the coefficient on university education by approximately 3\%, but it remains highly significant. However, if only income variables are added to only the baseline specification the coefficient becomes statistically insignificant, with approximately the same point value as the full specification with the full set of covariates.

\section{Conclusions}

This paper answers the question "Do more educated migrants remit more?” using micro level data. Our approach has the key advantage over other papers in this literature (Faini, 2007 and Niimi, et al. 2008) in that we are able to link the remittance decision of the migrant with their education level and therefore answer this question directly. In contrast, cross-country macroeconomic analyses which relate the amount of remittances received at a country level to the share of migrants with tertiary education are able at best to tell us whether countries which

\footnotetext{
${ }^{9}$ An alternative explanation may be that the high-earning highly educated are less likely to respond to surveys. Survey methods which draw a sample from areas which are known to have a high concentration of migrants (e.g. the Pew survey) or from sampling locations where migrants tend to congregate (e.g. the NiDi surveys) are particularly likely to miss highly educated high-income individuals who may be living in areas where there are less of their countrymen.
} 
send a larger share of highly skilled migrants receive less or more remittances than countries which send relatively fewer skilled migrants.

We pull together the most comprehensive database on migrants currently available, comprising over 33,000 migrants in 11 OECD countries. Using this database we examine exactly the decision between remittance decisions and education. Combining both the extensive margin (the decision to remit at all) and the intensive margin (the decision how much to remit), the fact is that more educated migrants do remit significantly more - migrants with an university degree remit \$300 more yearly than migrants without an university degree.

We are able to analyze several competing theoretical channels to understand this result. We find that differences in household composition between high and low skilled migrants do not explain the observed remittance behavior. One explanation may be that although low skilled migrants are more likely to have a spouse and children left in the home country, they have larger families in general than high skilled migrants and tend to live in larger households in the host country. In contrast, we find considerable support that an income effect is the dominant channel through which education operates. More educated migrants earn more money and for this reason remit more than low skilled migrants.

This paper has important implications for migration policy. There is much concern about the negative effects of the 'brain drain' on developing countries. However, our main finding that remittances increase with education, illustrates one beneficial dimension of high-skilled migration for developing countries. High skilled migrants work better jobs and earn more money than low skilled migrants, and in turn, send more money back home in remittance flows. This suggests that sending highly skilled migrants who are able to earn higher income is one way to increase remittance flows. 


\section{References}

Cox, D., Z. Eser and E. Jimenez (1998): Motives for private transfers over the life cycle: An analytical framework and evidence for Peru, Journal of Development Economics, 55: 57-80.

Cox, Donald (1987): Motives for private transfers, Journal of Political Economy, 95, 3: 508-46.

Docquier, Frédéric and Abdeslam Marfouk (2005) “International Migration by Education Attainment, 1990-2000”, pp. 151-99 in C. Özden and M. Schiff (eds.) International Migration, Remittances and the Brain Drain. New York: Palgrave, Macmillan.

Faini, Riccardo (2007) "Remittances and the Brain Drain: Do more skilled migrants remit more?”, World Bank Economic Review 21(2): 177-91.

Groenewold, George, and Richard Bilsborrow (2004) "Design of Samples for International Migration Surveys: Methodological Considerations, Practical Constraints and Lessons Learned from a Multi-Country Study in Africa and Europe”, Population Association of America 2004 General Conference.

IADB (2005) "Survey of Brazilians and Peruvians in Japan” commissioned by the Multilateral Investment Fund

Miotti, Luis, El Mouhoub Mouhoud, and Joel Oudinet (2009) "Migrations and Determinants of Remittances to Southern Mediterranean Countries: When History Matters”, Paper presented at the $2^{\text {nd }}$ Migration and Development Conference, Washington DC, September 10-11.

Niimi, Yoko, Çaglar Özden, and Maurice Schiff (2008) "Remittances and the Brain Drain: Skilled Migrants do remit less”, IZA Working Paper no. 3393.

OECD (2007) Policy Coherence for Development 2007: Migration and Developing Countries. OECD, Paris.

Rapoport, Hillel and Frederic Docquier (2006): The economics of migrants' remittances, in S.-C. Kolm and J. Mercier Ythier, eds.: Handbook of the Economics of Giving, Altruism and Reciprocity, North Holland, Chapter 17, pp. 1135-98.

Robinson, Peter M. (1988) “Root-N Consistent Semiparametric Regression”, Econometrica 56: 931-54.

Siegel, Melissa (2007) “Immigrant Integration and Remittance Channel Choice”, Working Paper

Stark, Oded (1991): The migration of labor, Oxford and Cambridge, MA: Basil Blackwell.

World Bank (2008) Migration and Remittances Factbook 2008. World Bank, Washington D.C.

World Bank (2009) "Migration and Development Brief No. 9", http://siteresources.worldbank.org/INTPROSPECTS/Resources/MD_Brief9_Mar2009.pdf [accessed July 10, 2009]. 


\section{Data Appendix}

This paper combines household surveys from many countries, all with different samples and questions. This appendix outlines the actual remittance questions asked in each survey and how all variables used in the paper were coded.

\section{General rules}

- Financial variables are annualized, converted to US dollars using nominal exchange rates from the Penn World Table, then deflated with the CPI to 2003 levels.

- To interpolate information provided only in binned categories, we infer:

0 Years of education as the midpoints of the schooling ranges

o Financial values as the geometric midpoints of the money ranges

o An upper bound on the highest category of twice level of the lower bound on this category

- "Don't know" is coded as missing. For example, about one-third of the "Will return home” indicator values are missing for this reason.

- We trim all reported remittances greater than twice annual (positive) income

\section{Country of birth}

We drop all migrants born in high income countries.

- Migrants are classified as being born in a High Income country based on the April 2009 World Bank list

- When only groupings of countries are provided for some observations, each grouping receives a new dataset-specific "country" code.

- Only the USA NIS dataset brings the previous two points into serious conflict. For this dataset, we must classify as "high income" everyone born in Europe \& Central Asia, except Poland, Russia and Ukraine. And our definition of a developing country in the NIS must include the high income countries: Antigua \& Barbuda, Aruba, Bahamas, Bahrain, Barbados, Brunei Darussalam, Cayman Islands, Cyprus, Equatorial Guinea, Faeroe Islands, French Polynesia, Guam, Hong Kong, Japan, Kuwait, Macao, Netherlands Antilles, New Caledonia, Northern Mariana Islands, Oman, Puerto Rico, Qatar, Saudi Arabia, Singapore, Trinidad \& Tobago, United Arab Emirates, Virgin Islands.

- The Belgium IRSHS dataset does not explicitly ask country of birth: we have assigned respondents their ethnicity as country of birth if they answered they were born outside of Belgium. 


\section{Sample weights}

We always use the sampling weights provided with each survey dataset. When pooling the datasets we start with these, and then re-scale the weights in three steps to allow comparisons across surveys, eventually using weights post-stratified by education and country of birth in our baseline results:

1. Weight each survey in proportion to its sample size. The weights in each survey were rescaled to sum to the number of observations of developing country migrants in that survey.

2. Post-stratify by education and continent of origin. After weighting each survey in proportion to its sample size, the surveys were pooled and divided into 8 cells: by 4 continents of birth and by whether the respondent had a university degree. The weights in each cell were then rescaled to sum to the total number of developing country migrants in OECD countries in this cell in the year 2000, from the Brain Drain database (Docquier and Marfouk 2005). Migrants in the Brain Drain database of unknown education were assigned an educational attainment in proportion to that of their compatriots so that country totals and relative skill fractions remained accurate.

3. Post-stratify by education and country of origin. After constructing the continental post-stratified weights, we calculate aggregate sample weights for each country in the continent as the sum across surveys of weights of observations of known countries, and of shares of weights of observations of groupings of unknown countries in the continent (eg, "Other Africa”), where the shares of each country within the grouping are calculated from the Brain Drain database. These aggregate sample weights are then re-scaled to the number of migrants in this country-by-education cell in the Brain Drain database. Finally, these total re-scaled weights are re-apportioned to the (sometimes survey-specific) country codes following the reverse procedure (ie, using shares from the Pooled data). In this way, we create weighting cells that, for each survey, partition each continent-byeducation cell, but allow different surveys to have different country grouping codes.

\section{Total Remittances}

Target definition Value of money and goods sent by household outside country in the past year

Australia LSIA "How much money have you (or your spouse who immigrated with you) sent to relatives or friends overseas since your last interview?” Annualized based on time since last interview

Belgium IRSHS "Over the past 12 months, what is the total value (in Euro) of money that you sent to this person in [x]" "What is the total value of goods that you sent to [x] over the past 12 months?"

France 2MO "During the last twelve months, in which category is the total transfers of money that you have made to your home country?"

France DREES $\quad \quad \quad$ Not available: Survey of extensive margin only 
Germany SOEP Have you personally given payments or support during the past year (1999) to relatives or other persons outside of your household? Summed over all household members

Italy NIDI

Japan IADB

Netherlands CSR

Norway LKI

Spain ENI

Spain NIDI

UK BME

USA NIS

USA Pew

\section{Remits Indicator}

Target definition

Australia LSIA

Belgium IRSHS

France $2 \mathrm{MO}$

France DREES

Germany SOEP

Italy NIDI
Following Remits questions: "About how much money was this in total, during these past twelve months?”

"How much money - on average - do you send each time you send money to a family member in Brazil?”

"How frequently do you send money to your family in Brazil?"

"How much money will you send each year to this country?"

x Not available: Survey of extensive margin only

"What is the total amount that you forwarded during the last year?"

Same as Italy NIDI

"Thinking now about the last 12 months, how much money do you think this household has sent to family or friends abroad? Please give an approximate value if you are not sure"

"How much [financial assistance (such as gifts, transfers, bequests, or loans)] you give during the last twelve months to [XXX] during periods when he/she was not living with you in the same house?" Asked about relatives, friends and employers. Also include "any non-financial assistance in the form of goods or materials” given to anyone other than spouse or children.

Includes some transfers for which the country of person [XXX] cannot be determined (less than one-third of total remittances)

Following Remit questions: “How often?” “On average, how much money do you send?”

1 if household sent money or goods outside country in the past year

"Since your last interview have you (or your spouse who immigrated with you) sent any money to relatives or friends overseas?” Annualized based on time since last interview

"Over the past 12 months, did you or anyone living in this residence send money to anybody in $[\mathrm{x}]$ ?"

$\boldsymbol{x}$ Not applicable: Survey of remitters, conducted at post office when remitting.

"Do you send or bring money to your home country?"

1 if answer to total remittance question (above) $>0$

1 if answers yes to "In the past twelve months, did you or anyone else in this household send or bring money to family, relatives or friends in your country of birth to be used for their own benefit?", or to "In the past twelve months, did you or anyone else in this household send or bring 
money to your country of birth which was used to benefit the community there?"

Japan IADB "Have you ever sent money to a family member in Brazil?"

Netherlands CSR × Not applicable: Survey of remitters. Respondent must answer “yes” to the question "Do you or your partner ever send money abroad" for survey to be administered.

Norway LKI "Do you send money regularly to family or relatives in the homeland? If so, to whom?”

Spain ENI "Do you send money overseas?"

Spain NIDI Same as Italy NIDI

UK BME $\quad \times$ Not applicable: Survey of remitters. Administered to HH only if had remitted to family and friends abroad within the last 12 months.

USA NIS Defined as positive total remittances. (A simple yes/no question was also asked, but only of $20 \%$ of the sample.)

USA Pew "Have you sent money to anyone (country of origin) over the past year?”

For the remaining variables, we simply note our target definition and any discrepancy from this for each dataset, using the following short-hand:

$\checkmark \quad$ The variable definition in this survey meets the target

$x \quad$ The variable is not available in this survey

\section{Education measured by University degree}

Target definition 1 if any migrant adult in household has a 3 year University degree or greater

Australia LSIA Only includes respondent and spouse-and only about one-third of spouses were interviewed

Belgium IRSHS

France 2MO

France DREES

Germany SOEP

Italy NIDI

Japan IADB

Netherlands CSR

Norway LKI

Spain ENI

Spain NIDI

UK BME

USA NIS

USA Pew

\section{$\checkmark$}

Only includes respondent

Only includes respondent, as spouse education categories not fine enough to distinguish university from high school graduation

Only includes respondent

Only includes respondent

Only includes respondent

Only includes respondent

$\checkmark$

Only includes respondent

Only includes respondent and spouse

Only includes respondent 


\section{Years of Education}

Target definition Maximum years of formal education of all migrant adults in household

Australia LSIA Continuous variable only for those with post-secondary education. For others, coded based on schooling categories. Only includes respondent and spouse — and only about one-third of spouses were interviewed

Belgium IRSHS

France 2MO

Only includes respondent

France DREES

Only includes respondent and spouse. For respondent, only observe freeresponse highest qualification. So assume doctors \& engineers have university, and all other trade certificates mentioned are equivalent to finishing high school. For spouse, only observe limited age at completion categories

Germany SOEP $\quad \checkmark$ Use the internally consistent variable coded to match highest educational qualification

Italy NIDI

$\checkmark$

Japan IADB

Only includes respondent

Netherlands CSR

Only includes respondent

Norway LKI

Only includes respondent

Spain ENI

Spain NIDI

Only includes respondent

UK BME

Only includes respondent

USA NIS

USA Pew

Only includes respondent, spouse, respondent's parents, \& children in household

Only includes respondent

\section{Income}

Target definition

After-tax household income in the past year

Australia LSIA

Values are before taxes and deductions

Belgium IRSHS

France 2MO

$\checkmark$

France DREES

Germany SOEP

Italy NIDI

Japan IADB

Netherlands CSR

Norway LKI

Spain ENI

Spain NIDI

Use personal income if missing information on household income

UK BME

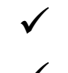

USA NIS

Is personal income, not household income

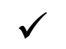

Values are before taxes and deductions

Values are before taxes and deductions 
USA Pew

\section{Working}

Target definition

Australia LSIA

Belgium IRSHS

France 2MO

France DREES

Germany SOEP

Italy NIDI

Japan IADB

Netherlands CSR

Norway LKI

Spain ENI

Spain NIDI

UK BME

USA NIS

USA Pew

\section{Household size}

Target definition

Australia LSIA

Belgium IRSHS

France 2MO

France DREES

Germany SOEP

Italy NIDI

Japan IADB

Netherlands CSR

Norway LKI

Spain ENI

Spain NIDI

UK BME

USA NIS

USA Pew
Values are before taxes and deductions

1 if any migrant adult in household is engaged in employment

Only includes respondent and spouse-and only about one-third of spouses were interviewed

Only includes respondent and spouse

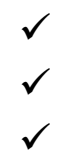

Coded on basis of "what most nearly describes the type of work you do?” $x$

Only includes respondent

Only includes respondent

$\checkmark$

Only includes respondent

Only includes respondent and spouse, and spouse coded on basis of "main occupation of this person during your marriage"

Only includes respondent

Number of people currently living in home of respondent

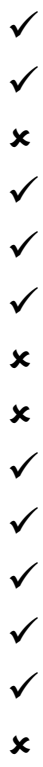




\section{Married and Spouse outside of country}

Married target 1 if main respondent is married

Spouse outside of 1 if main respondent is married to someone currently living outside country target country of survey

Australia LSIA $\checkmark$

Belgium IRSHS $\quad \times$ Neither variable available

France $2 \mathrm{MO}$

France DREES

Germany SOEP

Italy NIDI

Japan IADB

Netherlands CSR

Norway LKI

Spain ENI

Spain NIDI

UK BME

USA NIS

USA Pew

\section{$x$ Spouse outside country not available}

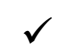

$\times$ Spouse outside country not available

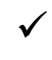

$x$

$x$ Neither variable available

$\checkmark$

$\checkmark$

$\checkmark$

$\boldsymbol{x}$ Neither variable available

$\checkmark$

$\times$ Spouse outside country not available

\section{Parents and Children, and Parents and Children outside of country}

Target definitions Numbers of alive parents and children related to main respondent and their spouse, and the numbers of these currently living outside country of survey

Australia LSIA These variables are for prior wave three years earlier, with the exception of children in household (which we use to update the total children count)

Belgium IRSHS

France $2 \mathrm{MO}$

France DREES

Germany SOEP

Italy NIDI

Japan IADB

Netherlands CSR

Norway LKI

Spain ENI $x$

$x$ Numbers of Parents and Children not available. Parents and Children outside country are coded only as indicator variables

x Have both Children variables, but neither Parents variables are available

* Have both parent variables, but children outside of country not available

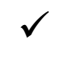

$x$

$x$ Number of parents and children not available. Children outside country coded only as an indicator variable

Underestimate parents outside country, as only includes location of respondents' parents, not spouses' too

Underestimate parents outside country, as only includes location of respondents' parents, not spouses' too 
Spain NIDI

UK BME

USA NIS

USA Pew

\section{$x$}

Underestimate parents outside country, as only includes location of respondents' parents, not spouses' too

$\boldsymbol{x}$ Only asks about how many children live in home country, but not spouse nor parents.

\section{Years spent abroad}

Target definition

Australia LSIA

Belgium IRSHS

France 2MO

France DREES

Germany SOEP

Italy NIDI

Japan IADB

Netherlands CSR

Norway LKI

Spain ENI

Spain NIDI

UK BME

USA NIS

USA Pew
Years main respondent has spent outside country of birth

Only includes time spent in Australia

"What year did migrate to Belgium?"

"How long have you lived in France?"

Year of interview minus year left country of birth permanently

2000 - year immigrated to Germany

Year of interview minus year of first emigration

"How many years have you been living in Japan?"

"How long have you lived in the Netherlands?"

$x$

"In which year did you arrive in Spain?"

Year of interview minus year of first emigration

"When did you come to live in the UK?"

Year of interview minus year first left country of birth for 60+ days

"How many years have you lived in the (continental) United States?"

\section{Legal immigrant indicator}

Target definition 1 if main respondent has nationally legal immigration status

Australia LSIA 1 by sampling definition

Belgium IRSHS $\quad x$

France 2MO $\quad \boldsymbol{x}$

France DREES 1 by sampling definition

Germany SOEP $\quad \mathbf{x}$

Italy NIDI "Did you have a visa or residence or work permits when you entered this country?”

Japan IADB $\quad \boldsymbol{x}$

Netherlands CSR $\quad \boldsymbol{x}$

Norway LKI $\quad x$

Spain ENI Coded yes if permanent resident; temporary resident; refugee; student; or European.

Spain NIDI Same as Italy NIDI

UK BME 
USA NIS

1 by sampling definition

USA Pew

$\mathbf{x}$

\section{Will return home indicator}

Target definition 1 if main respondent intends to return permanently to country of birth

Australia LSIA $\checkmark$

Belgium IRSHS $\boldsymbol{x}$

France 2MO

France DREES

Germany SOEP

Italy NIDI

Japan IADB

Netherlands CSR

Norway LKI

Spain ENI

Spain NIDI

UK BME

USA NIS

USA Pew

$\checkmark$

$\checkmark$

$\checkmark$ If respondent answers no to the question "Do you want to stay in Germany forever?”

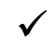

$x$

$x$

If answer plans to move to another country when asked if will stay in house.

$\checkmark$ Asks for the next five years

$\checkmark$

If respond "Very likely" or "quite likely" to the question "How likely are you to return abroad to live in the country you initially came from?"

Inverse of "Do you intend to live in the United States for the rest of your life?"

If doesn't answer "As long as you are able/can", or "All your life" to the question "How long to you think you will remain in the US?" 
Table 1: Migrant datasets

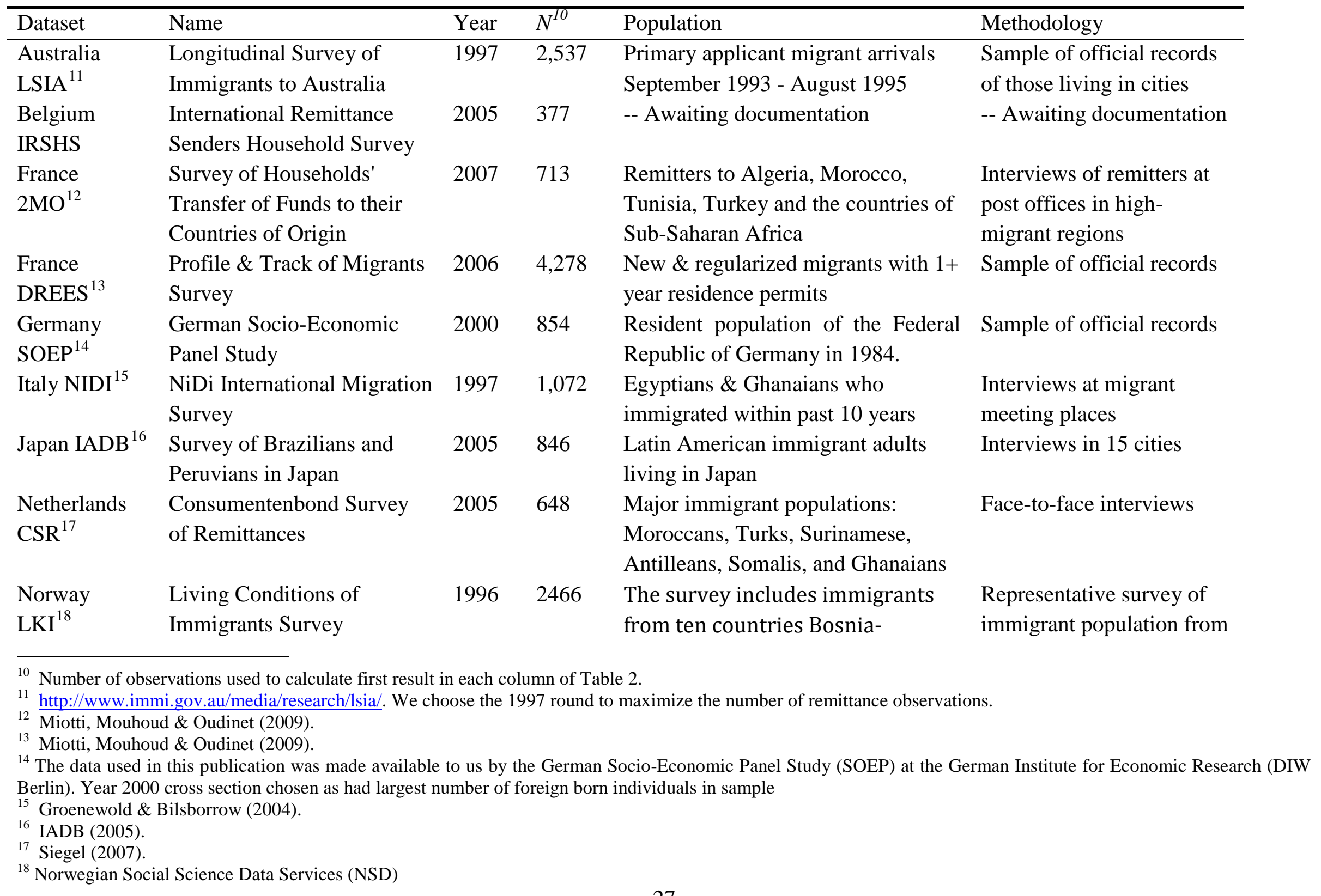




\begin{tabular}{|c|c|c|c|c|c|}
\hline Spain ENI ${ }^{19}$ & $\begin{array}{l}\text { National Survey of } \\
\text { Immigrants }\end{array}$ & 2006 & 9,234 & $\begin{array}{l}\text { Lanka, Turkey and Vietnam } \\
\text { Foreign-born who (intend to) live in } \\
\text { Spain for } 1+\text { years }\end{array}$ & $\begin{array}{l}\text { Sample of official } \\
\text { neighborhood rosters }\end{array}$ \\
\hline Spain NIDI ${ }^{20}$ & $\begin{array}{l}\text { NiDi International Migration } \\
\text { Survey }\end{array}$ & 1997 & 1,020 & $\begin{array}{l}\text { Moroccans \& Senegalese who } \\
\text { immigrated within past } 10 \text { years }\end{array}$ & $\begin{array}{l}\text { Geographical sampling, \& } \\
\text { references from sampled }\end{array}$ \\
\hline UK BME & $\begin{array}{l}\text { Black / Minority Ethnic } \\
\text { Remittance Survey }\end{array}$ & 2006 & 993 & $\begin{array}{l}\text { Migrant minorities who have } \\
\text { remitted in past } 12 \text { months }\end{array}$ & $\begin{array}{l}\text { Sampling of geographical } \\
\text { blocks }\end{array}$ \\
\hline USA NIS $^{21}$ & New Immigrant Survey & 2003 & 7,046 & $\begin{array}{l}\text { Migrants receiving green cards May } \\
\text { - Novermber } 1993\end{array}$ & Sample of official records \\
\hline USA Pew ${ }^{22}$ & $\begin{array}{l}\text { Pew National Survey of } \\
\text { Latinos }\end{array}$ & 2006 & 1,084 & $\begin{array}{l}\text { Nationally representative sample of } \\
\text { Latino respondents ages } 18 \text { and } \\
\text { older }\end{array}$ & $\begin{array}{l}\text { Sampled phone numbers in } \\
\text { high-Latino areas }\end{array}$ \\
\hline
\end{tabular}

\footnotetext{
${ }_{20} \mathrm{http}: / /$ www.ine.es/prodyser/micro_inmigra.htm

${ }^{20}$ Groenewold \& Bilsborrow (2004).

${ }^{21}$ http://nis.princeton.edu/.

22 http://pewhispanic.org/datasets/signup.php?DatasetID=7.
}

Herzegovina, Chile, Iraq, Iran, these countries

Pakistan, Serbia, Somalia, Sri

Lanka, Turkey and Vietnam

Spain for 1+ years

immigrated within past 10 years

Migrant minorities who have

remitted in past 12 months

Sampling of geographical

blocks

- Novermber 1993

Latino respondents ages 18 and high-Latino areas 
Table 2: Survey Means by Education

\begin{tabular}{|c|c|c|c|c|c|c|c|c|c|c|c|c|c|c|c|c|c|}
\hline & $\begin{array}{c}\text { Australia } \\
\text { LSIA }\end{array}$ & $\begin{array}{c}\text { Belgium } \\
\text { IRSHS }\end{array}$ & $\begin{array}{c}\text { France } \\
2 \mathrm{MO}\end{array}$ & $\begin{array}{l}\text { France } \\
\text { DREES }\end{array}$ & $\begin{array}{c}\text { Germany } \\
\text { SOEP }\end{array}$ & $\begin{array}{l}\text { Italy } \\
\text { NIDI }\end{array}$ & $\begin{array}{l}\text { Japan } \\
\text { IADB }\end{array}$ & $\begin{array}{l}\text { Netherlands } \\
\text { CSR }\end{array}$ & $\begin{array}{c}\text { Norway } \\
\text { LKI }\end{array}$ & $\begin{array}{c}\text { Spain } \\
\text { ENI }\end{array}$ & $\begin{array}{c}\text { Spain } \\
\text { NIDI }\end{array}$ & $\begin{array}{c}\text { UK } \\
\text { BME }\end{array}$ & $\begin{array}{l}\text { USA } \\
\text { NIS }\end{array}$ & $\begin{array}{l}\text { USA } \\
\text { Pew }\end{array}$ & $\begin{array}{c}\text { Pooled } \\
\text { Extensive }\end{array}$ & $\begin{array}{c}\text { Pooled } \\
\text { Intensive }\end{array}$ & $\begin{array}{c}\text { Pooled } \\
\text { Total }\end{array}$ \\
\hline Observations & 2,656 & 451 & 717 & 4,280 & 900 & 1,153 & 1,065 & 836 & 2,466 & 10,282 & 1,113 & 1,152 & 7,352 & 1,304 & 33,022 & 28,981 & 26,276 \\
\hline $\begin{array}{l}\text { Fraction with } \\
\text { University }\end{array}$ & 0.32 & 0.59 & 0.07 & 0.18 & 0.20 & 0.21 & 0.14 & 0.11 & 0.12 & 0.23 & 0.04 & 0.20 & 0.34 & 0.06 & 0.36 & 0.37 & 0.37 \\
\hline \multicolumn{18}{|c|}{ Total remittances (\$ p.a.) } \\
\hline No university & 286 & 1,681 & 1,380 & & 368 & 2,724 & 2,662 & 993 & & 988 & 3,099 & 2,691 & 375 & 1,530 & 699 & 793 & 650 \\
\hline University & 379 & $2,475^{*}$ & 1,652 & & 511 & 2,227 & 2,920 & $1,405^{*}$ & & $743^{* *}$ & 2,835 & 2,629 & $1,145^{* *}$ & $671^{* *}$ & 868 & 897 & 874 \\
\hline \multicolumn{18}{|c|}{ Fraction who remit } \\
\hline No university & 0.41 & 0.91 & & 0.23 & 0.18 & 0.60 & 0.80 & & 0.34 & 0.49 & 0.78 & & 0.15 & 0.54 & 0.31 & 0.32 & 0.32 \\
\hline University & 0.37 & 0.86 & & 0.23 & 0.20 & $0.45^{* *}$ & $0.90^{* *}$ & & 0.29 & $0.37^{* *}$ & $0.48^{* *}$ & & 0.17 & 0.43 & $0.27^{* *}$ & $0.27^{* *}$ & $0.27^{* *}$ \\
\hline \multicolumn{18}{|c|}{ Log remittances } \\
\hline No university & 5.78 & 6.92 & 6.62 & & 6.97 & 7.89 & 7.76 & 6.49 & & 7.15 & 7.99 & 6.77 & 7.01 & 7.34 & 6.96 & 6.82 & 6.91 \\
\hline University & $6.23^{* *}$ & $7.29^{* * *}$ & 6.92 & & 7.01 & 8.11 & 7.70 & $6.81^{* *}$ & & 7.22 & $8.49^{*}$ & 6.92 & $7.40^{* *}$ & 6.97 & 7.02 & $6.97^{*}$ & 7.00 \\
\hline \multicolumn{18}{|c|}{ Household income (\$ p.a.) } \\
\hline No university & 14,457 & 16,918 & 23,173 & 18,612 & 19,526 & 10,903 & 34,014 & & 32,467 & 14,066 & 9,074 & 44,631 & 33,297 & 22,417 & 22,624 & 23,583 & 21,964 \\
\hline \multicolumn{2}{|l|}{ Log income } & $25,534 * *$ & $31,301^{*}$ & & 21,984 & $13,302^{*}$ & $43,624^{* *}$ & & $41,995^{* *}$ & $19,914 * *$ & 10,168 & 50,565 & 61,084 & $34,729^{* *}$ & $38,948^{* *}$ & $38,669^{* *}$ & $39,087^{* *}$ \\
\hline No university & 9.5 & 9.5 & 9.8 & 9.6 & 9.8 & 9.3 & 10.2 & & 10.1 & 9.4 & 9.0 & 10.3 & 9.2 & 9.7 & 9.6 & 9.5 & 9.5 \\
\hline University & $9.8^{* *}$ & $9.8^{* *}$ & 10.0 & $9 \cdot 9^{* *}$ & 9.8 & 9.4 & 10.4 & & $10.3^{* *}$ & $9.7^{* *}$ & 9.2 & 10.4 & $10.0^{* *}$ & $10.2^{* * *}$ & $9.9^{* *}$ & $9.9^{* *}$ & $9.9^{* *}$ \\
\hline \multicolumn{18}{|l|}{ Working } \\
\hline No university & 0.48 & 0.70 & 0.87 & 0.80 & 0.63 & 0.82 & 0.93 & & 0.48 & 0.68 & 0.81 & 0.82 & 0.66 & 0.66 & 0.65 & 0.66 & 0.64 \\
\hline University & $0.67^{* *}$ & 0.74 & 0.86 & $0.86^{* *}$ & 0.67 & 0.87 & 0.93 & & $0.70^{* *}$ & $0.73^{* *}$ & 0.66 & $0.90^{* *}$ & $0.78^{* *}$ & $0.77^{*}$ & $0.75^{* *}$ & $0.74^{* *}$ & $0.73^{* *}$ \\
\hline \multicolumn{18}{|l|}{ Household size } \\
\hline No university & 3.81 & 1.88 & & 2.51 & 2.90 & 1.80 & & & 1.53 & 3.82 & 1.84 & 3.33 & 4.10 & & 3.44 & 3.73 & 3.76 \\
\hline University & $3.44^{* *}$ & $2.55^{* *}$ & & $1.90^{* *}$ & 2.58 & $2.16 * *$ & & & $1.76^{* *}$ & $3.19^{* *}$ & 1.95 & $3.04 *$ & $3.49^{* *}$ & & $3.17^{* *}$ & $3.35^{* *}$ & $3.36^{* *}$ \\
\hline \multicolumn{18}{|l|}{ Married } \\
\hline No university & 0.73 & & 0.72 & 0.65 & 0.67 & 0.61 & & & 0.56 & 0.47 & 0.64 & & 0.66 & 0.54 & 0.63 & 0.63 & 0.63 \\
\hline University & $0.80^{* *}$ & & $0.51^{* *}$ & $0.71^{*}$ & 0.59 & 0.60 & & & $0.48^{*}$ & $0.56^{* *}$ & 0.51 & & $0.86 * *$ & 0.56 & $0.73^{* *}$ & $0.74 * *$ & $0.74 * *$ \\
\hline \multicolumn{18}{|c|}{ Spouse outside country } \\
\hline No university & 0.03 & & & & & 0.25 & & & 0.05 & 0.06 & 0.42 & & 0.05 & & 0.05 & 0.05 & 0.06 \\
\hline University & $0.01 *$ & & & & & 0.19 & & & $0.01^{* *}$ & 0.05 & $0.10^{* *}$ & & $0.03^{* *}$ & & $0.03^{* *}$ & $0.03^{* *}$ & $0.03^{* *}$ \\
\hline \multicolumn{18}{|c|}{ Number of children } \\
\hline No university & 1.29 & & & 1.16 & 1.78 & 1.06 & & & 2.50 & 2.06 & 1.58 & & 2.25 & 2.37 & 1.99 & 2.05 & 2.03 \\
\hline University & 1.22 & & & $0.89^{* *}$ & $1.27^{* *}$ & 1.00 & & & $2.15^{* *}$ & $1.85 * *$ & $0.62^{* *}$ & & $1.35^{* *}$ & $1.81^{* *}$ & $1.37^{* *}$ & $1.37^{* *}$ & $1.37^{* *}$ \\
\hline \multicolumn{18}{|c|}{ Children outside country } \\
\hline No university & 0.21 & & 0.10 & 0.25 & & 0.71 & 0.20 & & 0.16 & 0.38 & 1.10 & & 0.73 & 0.49 & 0.45 & 0.48 & 0.50 \\
\hline University & $0.07^{* *}$ & & 0.06 & $0.17^{* *}$ & & $0.49^{*}$ & 0.15 & & 0.09 & $0.26 * *$ & $0.21 * *$ & & $0.31^{* *}$ & 0.37 & $0.24^{* *}$ & $0.25^{* *}$ & $0.25^{* *}$ \\
\hline \multicolumn{18}{|c|}{ Number of parents } \\
\hline No university & 1.97 & & & & 1.13 & 0.95 & & & 1.35 & 1.42 & 1.27 & & 2.18 & & 1.81 & 1.84 & 1.83 \\
\hline University & $2.32^{* *}$ & & & & 1.03 & $0.70^{* *}$ & & & 1.32 & $1.35^{* *}$ & 1.37 & & $2.74^{* *}$ & & $2.18^{* *}$ & $2.21^{* *}$ & $2.23^{* *}$ \\
\hline \multicolumn{18}{|c|}{ Parents outside country } \\
\hline No university & 1.48 & & 0.81 & & 0.42 & 0.94 & & & 1.03 & 1.01 & 1.23 & & 0.88 & & 0.98 & 0.98 & 1.00 \\
\hline University & $2.00^{* *}$ & & 0.88 & & 0.54 & $0.67^{* *}$ & & & $1.17^{*}$ & 1.04 & 1.33 & & $1.26 * *$ & & $1.30^{* *}$ & $1.31^{* *}$ & $1.31^{* *}$ \\
\hline \multicolumn{18}{|c|}{ Years spent abroad } \\
\hline No university & 3.70 & 9.32 & 17.90 & 4.00 & 19.20 & 6.69 & 8.35 & 18.46 & & 10.06 & 7.27 & 14.89 & 7.35 & 16.43 & 9.20 & 11.17 & 10.29 \\
\hline University & $3.91^{* *}$ & $12.28 * *$ & $12.70^{* *}$ & 4.21 & $13.51 * *$ & 7.02 & 9.18 & 19.36 & & $12.41^{* *}$ & 6.74 & 14.66 & 7.05 & 18.34 & $8.06 * *$ & $8.75^{* *}$ & $8.40^{* * *}$ \\
\hline \multicolumn{18}{|c|}{ Legal immigrant } \\
\hline No university & 1.00 & & & 1.00 & & 0.84 & & & & 0.51 & 0.66 & & 1.00 & & 0.87 & 0.84 & 0.85 \\
\hline University & 1.00 & & & 1.00 & & 0.85 & & & & $0.39 * *$ & $0.82^{*}$ & & 1.00 & & $0.85^{* *}$ & 0.84 & 0.84 \\
\hline Will return ho & & & & & & & & & & & & & & & & & \\
\hline No university & 0.02 & & 0.45 & 0.06 & 0.23 & 0.39 & & & 0.01 & 0.08 & 0.35 & 0.63 & 0.09 & 0.19 & 0.09 & 0.16 & 0.11 \\
\hline University & 0.04 & & $0.65^{* *}$ & $0.10^{*}$ & 0.17 & $0.53^{* *}$ & & & 0.02 & 0.08 & 0.51 & 0.70 & $0.13^{* *}$ & 0.14 & 0.09 & $0.12^{* *}$ & $0.09^{*}$ \\
\hline
\end{tabular}


Table 3: Coefficients from Regressions of Remittance Measures on Education

\begin{tabular}{|c|c|c|c|c|c|c|c|c|c|c|c|c|c|c|c|c|c|}
\hline & $\begin{array}{c}\text { Australia } \\
\text { LSIA }\end{array}$ & $\begin{array}{c}\text { Belgium } \\
\text { IRSHS }\end{array}$ & $\begin{array}{c}\text { France } \\
2 \mathrm{MO} \\
\end{array}$ & $\begin{array}{l}\text { France } \\
\text { DREES }\end{array}$ & $\begin{array}{l}\text { Germany } \\
\text { SOEP }\end{array}$ & $\begin{array}{l}\text { Italy } \\
\text { NIDI } \\
\end{array}$ & $\begin{array}{l}\text { Japan } \\
\text { IADB }\end{array}$ & $\begin{array}{l}\text { Netherlands } \\
\text { CSR }\end{array}$ & $\begin{array}{c}\text { Norway } \\
\text { LKI }\end{array}$ & $\begin{array}{c}\text { Spain } \\
\text { ENI }\end{array}$ & $\begin{array}{l}\text { Spain } \\
\text { NIDI }\end{array}$ & $\begin{array}{c}\text { UK } \\
\text { BME } \\
\end{array}$ & $\begin{array}{l}\text { USA } \\
\text { NIS }\end{array}$ & $\begin{array}{l}\text { USA } \\
\text { Pew }\end{array}$ & $\begin{array}{c}\text { Pooled } \\
\text { Extensive } \\
\end{array}$ & $\begin{array}{c}\text { Pooled } \\
\text { Intensive }\end{array}$ & $\begin{array}{c}\text { Pooled } \\
\text { Total } \\
\end{array}$ \\
\hline \multicolumn{18}{|c|}{ A. Education Measured by University Degree } \\
\hline $\begin{array}{l}\text { Total Remittances } \\
\text { (\$ per annum) }\end{array}$ & 58.4 & $922.8 * *$ & & & 291.0 & -526.6 & 237.5 & & & -92.6 & -168.8 & & $769.5^{* *}$ & $-554.0^{*}$ & & & $298.0^{*}$ \\
\hline Observations & 2,537 & 377 & & & 854 & 1,072 & 846 & & & 9,234 & 1,020 & & 7,046 & 1,084 & & & 24,033 \\
\hline $\begin{array}{l}\text { Extensive margin: } \\
\text { Remits indicator }\end{array}$ & -0.019 & -0.055 & & 0.014 & 0.042 & -0.065 & $0.091^{* *}$ & & 0.012 & $-0.049^{* *}$ & $-0.232^{* *}$ & & $0.038^{* *}$ & $-0.140^{*}$ & -0.018 & & -0.010 \\
\hline Observations & 2,654 & 451 & & 4,278 & 854 & 1,153 & 1,030 & & 2,466 & 10,282 & 1,112 & & 7,113 & 1,296 & 32,651 & & 25,907 \\
\hline $\begin{array}{l}\text { Intensive margin: } \\
\text { Log remittances }\end{array}$ & $0.341^{*}$ & $0.433^{* *}$ & 0.363 & & 0.492 & 0.073 & -0.057 & $0.333^{* *}$ & & 0.093 & $0.430^{*}$ & 0.168 & $0.397^{*}$ & -0.199 & & $0.249^{* *}$ & $0.226^{* *}$ \\
\hline Observations & 958 & 317 & 713 & & 184 & 545 & 690 & 648 & & 3,966 & 761 & 993 & 1,118 & 514 & & 11,392 & 9,038 \\
\hline \multicolumn{18}{|c|}{ B. Education Measured by Years of Schooling } \\
\hline $\begin{array}{l}\text { Total Remittances } \\
(\$ \text { per annum) }\end{array}$ & $19.08^{*}$ & 86.50 & & & 26.39 & -7.56 & -3.03 & & & 2.40 & -13.65 & & 86.53 & 64.89 & & & 57.81 \\
\hline Observations & 2,531 & 377 & & & 854 & 1,072 & 846 & & & 9,164 & 1,020 & & 7,033 & 1,084 & & & 23,944 \\
\hline $\begin{array}{l}\text { Extensive margin: } \\
\text { Remits indicator }\end{array}$ & 0.0080 & -0.0042 & & 0.0018 & 0.0145 & 0.0010 & $0.0024^{* *}$ & & 0.0008 & -0.0023 & $-0.0072^{* *}$ & & $0.0034^{* *}$ & 0.0010 & 0.0006 & & 0.0014 \\
\hline Observations & 2,648 & 451 & & 5,529 & 854 & 1,153 & 1,030 & & 2,450 & 10,201 & 1,112 & & 7,100 & 1,296 & 32,535 & & 25,807 \\
\hline $\begin{array}{l}\text { Intensive margin: } \\
\text { Log remittances }\end{array}$ & $0.0441^{*}$ & 0.0341 & $0.0224^{*}$ & & -0.0085 & -0.0032 & -0.0040 & $0.0247^{*}$ & & $0.0199^{* *}$ & 0.0091 & $0.0548^{*}$ & $0.0329^{*}$ & 0.0369 & & $0.0256^{* *}$ & $0.0229^{* *}$ \\
\hline Observations & 956 & 317 & 713 & & 184 & 545 & 690 & 648 & & 3,942 & 761 & 993 & 1,116 & 514 & & 11,364 & 9,010 \\
\hline \multicolumn{18}{|c|}{ C. Means } \\
\hline $\begin{array}{l}\text { Total Remittances } \\
\text { (\$ per annum) }\end{array}$ & 316 & 2,159 & 1,399 & & 396 & 2,621 & 2,692 & 1,040 & & 932 & 3,089 & 2,679 & 633 & 1,479 & 764 & 2,466 & 734 \\
\hline Fraction who Remit & 0.40 & 0.85 & & 0.23 & 0.19 & 0.53 & 0.77 & & 0.34 & 0.41 & 0.75 & & 0.15 & 0.46 & 0.30 & 1.00 & 0.27 \\
\hline Frac. with University & 0.32 & 0.60 & 0.07 & 0.18 & 0.20 & 0.21 & 0.12 & 0.11 & 0.12 & 0.23 & 0.04 & 0.20 & 0.33 & 0.06 & 0.36 & 0.31 & 0.38 \\
\hline Years of Education & 13.4 & 14.2 & 7.7 & 12.0 & 11.5 & 14.1 & 13.3 & 10.7 & 12.2 & 11.4 & 7.5 & 13.4 & 13.4 & 9.4 & 12.9 & 12.3 & 13.0 \\
\hline
\end{tabular}

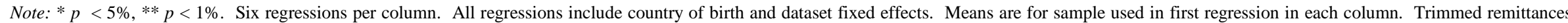
greater than twice annual income. Pooled sample weights post-stratified by education and country of birth. 
Table 4: Remittance Measures on Years of Schooling for Pooled Sample with All Controls

\begin{tabular}{|c|c|c|c|}
\hline & $\begin{array}{c}\text { Total } \\
\text { Remittances }\end{array}$ & $\begin{array}{c}\text { Extensive } \\
\text { Remits }\end{array}$ & $\begin{array}{c}\text { Intensive } \\
\text { Log remittances }\end{array}$ \\
\hline Years of education & $\begin{array}{c}37.81 \\
(29.64)\end{array}$ & $\begin{array}{l}-0.002 * \\
(0.001)\end{array}$ & $\begin{array}{l}0.017 * * \\
(0.005)\end{array}$ \\
\hline Log income & $\begin{array}{l}384.59 * * \\
(105 \cdot 37)\end{array}$ & $\begin{array}{l}0.023 * * \\
(0.003)\end{array}$ & $\begin{array}{l}0.364 * * \\
(0.034)\end{array}$ \\
\hline Working & $\begin{array}{c}345.06 * * \\
(90.80)\end{array}$ & $\begin{array}{l}0.113^{* *} \\
(0.010)\end{array}$ & $\begin{array}{l}0.514 * * \\
(0.065)\end{array}$ \\
\hline Household size & $\begin{array}{c}-8.14 \\
(17.67)\end{array}$ & $\begin{array}{l}-0.002 \\
(0.002)\end{array}$ & $\begin{array}{c}0.015 \\
(0.016)\end{array}$ \\
\hline Married & $\begin{array}{l}-89.77 \\
(68.78)\end{array}$ & $\begin{array}{c}0.004 \\
(0.010)\end{array}$ & $\begin{array}{l}-0.097 \\
(0.061)\end{array}$ \\
\hline Spouse outside country & $\begin{array}{c}1,120.95^{* *} \\
(236.04)\end{array}$ & $\begin{array}{l}0.145^{* *} \\
(0.020)\end{array}$ & $\begin{array}{l}0.568 * * \\
(0.097)\end{array}$ \\
\hline Number of children & $\begin{array}{c}-121.56 * * \\
(36.44)\end{array}$ & $\begin{array}{l}-0.006 \\
(0.003)\end{array}$ & $\begin{array}{c}-0.099 * * \\
(0.027)\end{array}$ \\
\hline Children outside country & $\begin{array}{c}337.78 * * \\
(75.14)\end{array}$ & $\begin{array}{l}0.048 * * \\
(0.006)\end{array}$ & $\begin{array}{l}0.228 * * \\
(0.039)\end{array}$ \\
\hline Number of parents & $\begin{array}{l}-47.07 \\
(53.56)\end{array}$ & $\begin{array}{l}-0.020 * * \\
(0.005)\end{array}$ & $\begin{array}{l}-0.125^{* *} \\
(0.045)\end{array}$ \\
\hline Parents outside country & $\begin{array}{c}182.58 * * \\
(38.02)\end{array}$ & $\begin{array}{l}0.063^{* *} \\
(0.006)\end{array}$ & $\begin{array}{l}0.243 * * \\
(0.045)\end{array}$ \\
\hline Years spent abroad / 100 & $\begin{array}{c}2,539.77 \\
(2,533.08)\end{array}$ & $\begin{array}{l}0.251 * * \\
(0.095)\end{array}$ & $\begin{array}{l}1.744^{* *} \\
(0.656)\end{array}$ \\
\hline Years spent abroad squared / 100 & $\begin{array}{l}-31.43 \\
(27.14)\end{array}$ & $\begin{array}{l}-0.010 * * \\
(0.002)\end{array}$ & $\begin{array}{l}-0.033^{*} \\
(0.015)\end{array}$ \\
\hline Legal immigrant & $\begin{array}{c}398.79 * * \\
(121.36)\end{array}$ & $\begin{array}{l}0.096 * * \\
(0.018)\end{array}$ & $\begin{array}{l}0.167 * * \\
(0.061)\end{array}$ \\
\hline Will return home & $\begin{array}{l}692.30 * * \\
(201.83)\end{array}$ & $\begin{array}{l}0.095 * * \\
(0.021)\end{array}$ & $\begin{array}{c}0.085 \\
(0.072)\end{array}$ \\
\hline Number of observations & 23,944 & 32,535 & 11,364 \\
\hline
\end{tabular}

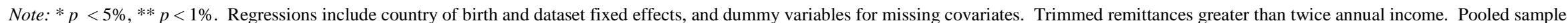
weights post-stratified by education and country of birth. 
Table 5: Education Coefficient as Controls are Added: Total Remittances

\begin{tabular}{|c|c|c|c|c|c|c|c|c|c|c|}
\hline & $\begin{array}{c}\text { Australia } \\
\text { LSIA }\end{array}$ & $\begin{array}{c}\text { Belgium } \\
\text { IRSHS }\end{array}$ & $\begin{array}{c}\text { Germany } \\
\text { SOEP }\end{array}$ & $\begin{array}{l}\text { Italy } \\
\text { NIDI }\end{array}$ & $\begin{array}{l}\text { Japan } \\
\text { IADB }\end{array}$ & $\begin{array}{c}\text { Spain } \\
\text { ENI }\end{array}$ & $\begin{array}{l}\text { Spain } \\
\text { NIDI }\end{array}$ & $\begin{array}{l}\text { USA } \\
\text { NIS }\end{array}$ & $\begin{array}{l}\text { USA } \\
\text { Pew }\end{array}$ & $\begin{array}{c}\text { Pooled } \\
\text { Total }\end{array}$ \\
\hline \multicolumn{11}{|c|}{ A. Education Measured by University Degree } \\
\hline Baseline & $\begin{array}{l}58.4 \\
(61.1)\end{array}$ & $\begin{array}{c}922.8 * * \\
(351.4)\end{array}$ & $\begin{array}{c}291.0 \\
(275.6)\end{array}$ & $\begin{array}{l}-526.6 \\
(411.6)\end{array}$ & $\begin{array}{c}237.5 \\
(374.1)\end{array}$ & $\begin{array}{c}-92.6 \\
(62.8)\end{array}$ & $\begin{array}{c}-168.8 \\
(749.4)\end{array}$ & $\begin{array}{l}769.5 * * \\
(254.4)\end{array}$ & $\begin{array}{l}-554.0 * \\
(227.2)\end{array}$ & $\begin{array}{l}298.0 * \\
(137.6)\end{array}$ \\
\hline Income & $\begin{array}{c}-10.1 \\
(62.4)\end{array}$ & $\begin{array}{l}557.0 * \\
(281.4)\end{array}$ & $\begin{array}{c}238.5 \\
(262.2)\end{array}$ & $\begin{array}{l}-623.9 \\
(407.2)\end{array}$ & $\begin{array}{c}166.5 \\
(359.8)\end{array}$ & $\begin{array}{c}-189.3^{* *} \\
(63.5)\end{array}$ & $\begin{array}{c}24.7 \\
(729.0)\end{array}$ & $\begin{array}{l}396.6 * \\
(174.4)\end{array}$ & $\begin{array}{l}-741.5^{* *} \\
(263.8)\end{array}$ & $\begin{array}{c}102.3 \\
(92.8)\end{array}$ \\
\hline Family & $\begin{array}{c}29.8 \\
(61.4)\end{array}$ & $\begin{array}{c}534.7 \\
(310.5)\end{array}$ & $\begin{array}{c}237.8 \\
(243.5)\end{array}$ & $\begin{array}{l}-306.7 \\
(394.7)\end{array}$ & $\begin{array}{c}317.5 \\
(380.3)\end{array}$ & $\begin{array}{l}-112.8 \\
(57.6)\end{array}$ & $\begin{array}{c}-6.9 \\
(725.9)\end{array}$ & $\begin{array}{l}623.6 * * \\
(204.7)\end{array}$ & $\begin{array}{c}-698.6 * * \\
(241.9)\end{array}$ & $\begin{array}{l}228.2 * \\
(103.1)\end{array}$ \\
\hline All & $\begin{array}{l}-16.5 \\
(62.1)\end{array}$ & $\begin{array}{c}475.8 \\
(272.7)\end{array}$ & $\begin{array}{c}144.6 \\
(179.8)\end{array}$ & $\begin{array}{l}-539.6 \\
(383.3)\end{array}$ & $\begin{array}{c}328.7 \\
(365.3)\end{array}$ & $\begin{array}{c}-181.7^{* *} \\
(58.6)\end{array}$ & $\begin{array}{c}266.2 \\
(698.6)\end{array}$ & $\begin{array}{l}402.2^{* *} \\
(154.3)\end{array}$ & $\begin{array}{c}-835.7^{* *} \\
(269.9)\end{array}$ & $\begin{array}{c}99.9 \\
(71.6)\end{array}$ \\
\hline Observations & 2,537 & 377 & 854 & 1,072 & 846 & 9,234 & 1,020 & 7,046 & 1,084 & 24,033 \\
\hline \multicolumn{11}{|c|}{ B. Education Measured by Years of Schooling } \\
\hline Baseline & $\begin{array}{c}19.08 * \\
(9.01)\end{array}$ & $\begin{array}{l}86.50 \\
(45.11)\end{array}$ & $\begin{array}{c}26.39 \\
(29.37)\end{array}$ & $\begin{array}{c}-7.56 \\
(34.05)\end{array}$ & $\begin{array}{l}-3.03 \\
(7.92)\end{array}$ & $\begin{array}{c}2.40 \\
(7.36)\end{array}$ & $\begin{array}{c}-13.65 \\
(19.95)\end{array}$ & $\begin{array}{c}86.53 \\
(46.50)\end{array}$ & $\begin{array}{c}64.89 \\
(44.97)\end{array}$ & $\begin{array}{c}57.81 \\
(37.08)\end{array}$ \\
\hline Income & $\begin{array}{c}7.99 \\
(8.69)\end{array}$ & $\begin{array}{c}47.80 \\
(38.28)\end{array}$ & $\begin{array}{c}3.51 \\
(27.33)\end{array}$ & $\begin{array}{l}-32.44 \\
(33.39)\end{array}$ & $\begin{array}{c}-2.59 \\
(11.50)\end{array}$ & $\begin{array}{l}-13.39 \\
(7.41)\end{array}$ & $\begin{array}{l}-26.95 \\
(19.68)\end{array}$ & $\begin{array}{c}44.98 \\
(40.00)\end{array}$ & $\begin{array}{c}49.18 \\
(45.09)\end{array}$ & $\begin{array}{c}32.12 \\
(31.98)\end{array}$ \\
\hline Family & $\begin{array}{c}17.03 \\
(8.98)\end{array}$ & $\begin{array}{c}29.28 \\
(38.45)\end{array}$ & $\begin{array}{c}25.56 \\
(27.79)\end{array}$ & $\begin{array}{c}47.31 \\
(34.93)\end{array}$ & $\begin{array}{c}-1.86 \\
(8.62)\end{array}$ & $\begin{array}{c}3.93 \\
(6.84)\end{array}$ & $\begin{array}{c}10.32 \\
(19.98)\end{array}$ & $\begin{array}{c}80.78 \\
(44.75)\end{array}$ & $\begin{array}{c}47.95 \\
(46.37)\end{array}$ & $\begin{array}{c}55.43 \\
(34.24)\end{array}$ \\
\hline All & $\begin{array}{c}8.86 \\
(8.91)\end{array}$ & $\begin{array}{c}33.77 \\
(36.94)\end{array}$ & $\begin{array}{c}9.66 \\
(22.82)\end{array}$ & $\begin{array}{c}22.64 \\
(32.79)\end{array}$ & $\begin{array}{c}1.99 \\
(10.63)\end{array}$ & $\begin{array}{c}-7.57 \\
(6.84)\end{array}$ & $\begin{array}{c}4.50 \\
(19.32)\end{array}$ & $\begin{array}{c}54.81 \\
(37.32)\end{array}$ & $\begin{array}{c}27.01 \\
(46.38)\end{array}$ & $\begin{array}{c}37.81 \\
(29.64)\end{array}$ \\
\hline Observations & 2,531 & 377 & 854 & 1,072 & 846 & 9,164 & 1,020 & 7,033 & 1,084 & 23,944 \\
\hline
\end{tabular}

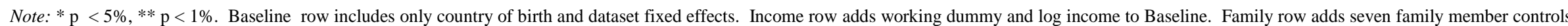
to Baseline. All row is full specification from Table 4 . Trimmed remittances greater than twice annual income. Pooled sample weights post-stratified by education and country of birth. 
Table 6: Education Coefficient as Controls are Added: Remits Indicator

\begin{tabular}{|c|c|c|c|c|c|c|c|c|c|c|c|c|c|}
\hline & $\begin{array}{c}\text { Australia } \\
\text { LSIA }\end{array}$ & $\begin{array}{l}\text { Belgium } \\
\text { IRSHS }\end{array}$ & $\begin{array}{l}\text { France } \\
\text { DREES }\end{array}$ & $\begin{array}{c}\text { Germany } \\
\text { SOEP }\end{array}$ & $\begin{array}{l}\text { Italy } \\
\text { NIDI }\end{array}$ & $\begin{array}{l}\text { Japan } \\
\text { IADB }\end{array}$ & $\begin{array}{c}\text { Norway } \\
\text { LKI }\end{array}$ & $\begin{array}{c}\text { Spain } \\
\text { ENI }\end{array}$ & $\begin{array}{l}\text { Spain } \\
\text { NIDI }\end{array}$ & $\begin{array}{l}\text { USA } \\
\text { NIS }\end{array}$ & $\begin{array}{l}\text { USA } \\
\text { Pew }\end{array}$ & $\begin{array}{c}\text { Pooled } \\
\text { Extensive }\end{array}$ & $\begin{array}{c}\text { Pooled } \\
\text { Total }\end{array}$ \\
\hline \multicolumn{14}{|c|}{ A. Education Measured by University Degree } \\
\hline Baseline & $\begin{array}{c}-0.019 \\
(0.032)\end{array}$ & $\begin{array}{c}-0.055 \\
(0.029)\end{array}$ & $\begin{array}{c}0.014 \\
(0.027)\end{array}$ & $\begin{array}{c}0.042 \\
(0.048)\end{array}$ & $\begin{array}{l}-0.065 \\
(0.043)\end{array}$ & $\begin{array}{l}0.091 * * \\
(0.034)\end{array}$ & $\begin{array}{c}0.012 \\
(0.030)\end{array}$ & $\begin{array}{c}-0.049 * * \\
(0.015)\end{array}$ & $\begin{array}{c}-0.232 * * \\
(0.081)\end{array}$ & $\begin{array}{c}0.038 * * \\
(0.011)\end{array}$ & $\begin{array}{l}-0.140 * \\
(0.060)\end{array}$ & $\begin{array}{c}-0.018 \\
(0.010)\end{array}$ & $\begin{array}{c}-0.010 \\
(0.010)\end{array}$ \\
\hline Income & $\begin{array}{l}-0.052 \\
(0.032)\end{array}$ & $\begin{array}{l}-0.112 * * \\
(0.029)\end{array}$ & $\begin{array}{c}-0.027 \\
(0.027)\end{array}$ & $\begin{array}{c}0.023 \\
(0.047)\end{array}$ & $\begin{array}{c}-0.074 \\
(0.042)\end{array}$ & $\begin{array}{l}0.082^{*} \\
(0.035)\end{array}$ & $\begin{array}{l}-0.020 \\
(0.030)\end{array}$ & $\begin{array}{c}-0.062^{* *} \\
(0.015)\end{array}$ & $\begin{array}{l}-0.185^{*} \\
(0.078)\end{array}$ & $\begin{array}{l}-0.000 \\
(0.011)\end{array}$ & $\begin{array}{l}-0.165^{* *} \\
(0.058)\end{array}$ & $\begin{array}{c}-0.043^{* *} \\
(0.010)\end{array}$ & $\begin{array}{c}-0.033^{* *} \\
(0.011)\end{array}$ \\
\hline Family & $\begin{array}{l}-0.062 \\
(0.032)\end{array}$ & $\begin{array}{l}-0.069 * \\
(0.032)\end{array}$ & $\begin{array}{c}0.015 \\
(0.027)\end{array}$ & $\begin{array}{c}0.039 \\
(0.048)\end{array}$ & $\begin{array}{l}-0.046 \\
(0.041)\end{array}$ & $\begin{array}{l}0.088 * \\
(0.035)\end{array}$ & $\begin{array}{l}-0.004 \\
(0.030)\end{array}$ & $\begin{array}{c}-0.067^{* *} \\
(0.013)\end{array}$ & $\begin{array}{l}-0.234^{* *} \\
(0.081)\end{array}$ & $\begin{array}{c}0.022 \\
(0.012)\end{array}$ & $\begin{array}{l}-0.148 * \\
(0.060)\end{array}$ & $\begin{array}{l}-0.031 * * \\
(0.010)\end{array}$ & $\begin{array}{c}-0.026 * \\
(0.011)\end{array}$ \\
\hline All & $\begin{array}{l}-0.080 * \\
(0.031)\end{array}$ & $\begin{array}{l}-0.113^{* *} \\
(0.030)\end{array}$ & $\begin{array}{c}-0.027 \\
(0.027)\end{array}$ & $\begin{array}{c}0.028 \\
(0.048)\end{array}$ & $\begin{array}{l}-0.065 \\
(0.038)\end{array}$ & $\begin{array}{l}0.083^{*} \\
(0.035)\end{array}$ & $\begin{array}{c}-0.031 \\
(0.030)\end{array}$ & $\begin{array}{l}-0.073^{* *} \\
(0.014)\end{array}$ & $\begin{array}{l}-0.177^{*} \\
(0.075)\end{array}$ & $\begin{array}{c}0.006 \\
(0.012)\end{array}$ & $\begin{array}{l}-0.161 * * \\
(0.059)\end{array}$ & $\begin{array}{c}-0.043^{* *} \\
(0.010)\end{array}$ & $\begin{array}{c}-0.033 * * \\
(0.011)\end{array}$ \\
\hline Observations & 2,654 & 451 & 4,278 & 854 & 1,153 & 1,030 & 2,466 & 10,282 & 1,112 & 7,113 & 1,296 & 32,651 & 25,907 \\
\hline \multicolumn{14}{|c|}{ B. Education Measured by Years of Schooling } \\
\hline Baseline & $\begin{array}{c}0.0080 \\
(0.0043)\end{array}$ & $\begin{array}{c}-0.0042 \\
(0.0040)\end{array}$ & $\begin{array}{c}0.0018 \\
(0.0025)\end{array}$ & $\begin{array}{c}0.0145 \\
(0.0084)\end{array}$ & $\begin{array}{c}0.0010 \\
(0.0040)\end{array}$ & $\begin{array}{l}0.0024^{* *} \\
(0.0005)\end{array}$ & $\begin{array}{c}0.0008 \\
(0.0025)\end{array}$ & $\begin{array}{l}-0.0023 \\
(0.0018)\end{array}$ & $\begin{array}{c}-0.0072 * * \\
(0.0021)\end{array}$ & $\begin{array}{c}0.0034 * * \\
(0.0012)\end{array}$ & $\begin{array}{c}0.0010 \\
(0.0060)\end{array}$ & $\begin{array}{c}0.0006 \\
(0.0009)\end{array}$ & $\begin{array}{c}0.0014 \\
(0.0010)\end{array}$ \\
\hline Income & $\begin{array}{c}0.0014 \\
(0.0042)\end{array}$ & $\begin{array}{l}-0.0117 * * \\
(0.0040)\end{array}$ & $\begin{array}{c}-0.0016 \\
(0.0025)\end{array}$ & $\begin{array}{c}0.0071 \\
(0.0084)\end{array}$ & $\begin{array}{c}-0.0027 \\
(0.0037)\end{array}$ & $\begin{array}{c}0.0035 * * \\
(0.0011)\end{array}$ & $\begin{array}{c}-0.0027 \\
(0.0026)\end{array}$ & $\begin{array}{c}-0.0049 * * \\
(0.0018)\end{array}$ & $\begin{array}{c}-0.0074 * * \\
(0.0021)\end{array}$ & $\begin{array}{l}-0.0015 \\
(0.0012)\end{array}$ & $\begin{array}{l}-0.0035 \\
(0.0057)\end{array}$ & $\begin{array}{c}-0.0027^{* *} \\
(0.0010)\end{array}$ & $\begin{array}{l}-0.0018 \\
(0.0010)\end{array}$ \\
\hline Family & $\begin{array}{c}0.0018 \\
(0.0044)\end{array}$ & $\begin{array}{l}-0.0060 \\
(0.0042)\end{array}$ & $\begin{array}{l}0.0050 * \\
(0.0025)\end{array}$ & $\begin{array}{c}0.0152 \\
(0.0087)\end{array}$ & $\begin{array}{c}0.0062 \\
(0.0041)\end{array}$ & $\begin{array}{l}0.0019 * * \\
(0.0006)\end{array}$ & $\begin{array}{l}-0.0006 \\
(0.0026)\end{array}$ & $\begin{array}{l}-0.0040 * \\
(0.0017)\end{array}$ & $\begin{array}{l}-0.0054^{*} \\
(0.0021)\end{array}$ & $\begin{array}{l}0.0029 * \\
(0.0012)\end{array}$ & $\begin{array}{c}0.0006 \\
(0.0060)\end{array}$ & $\begin{array}{c}0.0000 \\
(0.0009)\end{array}$ & $\begin{array}{c}0.0006 \\
(0.0010)\end{array}$ \\
\hline All & $\begin{array}{l}-0.0025 \\
(0.0041)\end{array}$ & $\begin{array}{l}-0.0115 * * \\
(0.0041)\end{array}$ & $\begin{array}{c}0.0012 \\
(0.0024)\end{array}$ & $\begin{array}{c}0.0130 \\
(0.0087)\end{array}$ & $\begin{array}{c}0.0031 \\
(0.0037)\end{array}$ & $\begin{array}{l}0.0034 * * \\
(0.0010)\end{array}$ & $\begin{array}{l}-0.0037 \\
(0.0026)\end{array}$ & $\begin{array}{c}-0.0061 * * \\
(0.0017)\end{array}$ & $\begin{array}{l}-0.0046^{*} \\
(0.0020)\end{array}$ & $\begin{array}{c}0.0002 \\
(0.0012)\end{array}$ & $\begin{array}{l}-0.0059 \\
(0.0055)\end{array}$ & $\begin{array}{l}-0.0019 * \\
(0.0010)\end{array}$ & $\begin{array}{c}-0.0011 \\
(0.0010)\end{array}$ \\
\hline Observations & 2,648 & 451 & 5,529 & 854 & 1,153 & 1,030 & 2,450 & 10,201 & 1,112 & 7,100 & 1,296 & 32,535 & 25,807 \\
\hline
\end{tabular}

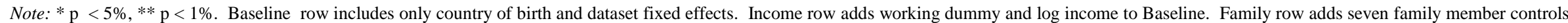
to Baseline. All row is full specification from Table 4 . Trimmed remittances greater than twice annual income. Pooled sample weights post-stratified by education and country of birth. 
Table 7: Education Coefficient as Controls are Added: Log Remittances

\begin{tabular}{|c|c|c|c|c|c|c|c|c|c|c|c|c|c|c|}
\hline & $\begin{array}{c}\text { Australia } \\
\text { LSIA }\end{array}$ & $\begin{array}{l}\text { Belgium } \\
\text { IRSHS }\end{array}$ & $\begin{array}{c}\text { France } \\
2 \mathrm{MO}\end{array}$ & $\begin{array}{l}\text { Germany } \\
\text { SOEP }\end{array}$ & $\begin{array}{l}\text { Italy } \\
\text { NIDI }\end{array}$ & $\begin{array}{l}\text { Japan } \\
\text { IADB }\end{array}$ & $\begin{array}{c}\text { Netherlands } \\
\text { CSR }\end{array}$ & $\begin{array}{l}\text { Spain } \\
\text { ENI }\end{array}$ & $\begin{array}{l}\text { Spain } \\
\text { NIDI }\end{array}$ & $\begin{array}{c}\text { UK } \\
\text { BME }\end{array}$ & $\begin{array}{l}\text { USA } \\
\text { NIS }\end{array}$ & $\begin{array}{l}\text { USA } \\
\text { Pew }\end{array}$ & $\begin{array}{c}\text { Pooled } \\
\text { Intensive }\end{array}$ & $\begin{array}{l}\text { Pooled } \\
\text { Total }\end{array}$ \\
\hline \multicolumn{15}{|c|}{ A. Education Measured by University Degree } \\
\hline Baseline & $\begin{array}{l}0.341^{*} \\
(0.145)\end{array}$ & $\begin{array}{c}0.433 * * \\
(0.131)\end{array}$ & $\begin{array}{l}0.363 \\
(0.211)\end{array}$ & $\begin{array}{c}0.492 \\
(0.450)\end{array}$ & $\begin{array}{c}0.073 \\
(0.171)\end{array}$ & $\begin{array}{l}-0.057 \\
(0.146)\end{array}$ & $\begin{array}{l}0.333^{* *} \\
(0.116)\end{array}$ & $\begin{array}{c}0.093 \\
(0.066)\end{array}$ & $\begin{array}{l}0.430 * \\
(0.202)\end{array}$ & $\begin{array}{c}0.168 \\
(0.133)\end{array}$ & $\begin{array}{l}0.397^{*} \\
(0.169)\end{array}$ & $\begin{array}{l}-0.199 \\
(0.216)\end{array}$ & $\begin{array}{l}0.249 * * \\
(0.060)\end{array}$ & $\begin{array}{l}0.226 * * \\
(0.071)\end{array}$ \\
\hline Income & $\begin{array}{c}0.237 \\
(0.138)\end{array}$ & $\begin{array}{l}0.243^{*} \\
(0.116)\end{array}$ & $\begin{array}{c}0.306 \\
(0.203)\end{array}$ & $\begin{array}{c}0.408 \\
(0.445)\end{array}$ & $\begin{array}{c}0.021 \\
(0.165)\end{array}$ & $\begin{array}{l}-0.086 \\
(0.140)\end{array}$ & $\begin{array}{l}0.333^{* *} \\
(0.116)\end{array}$ & $\begin{array}{c}0.040 \\
(0.064)\end{array}$ & $\begin{array}{c}0.367 \\
(0.200)\end{array}$ & $\begin{array}{c}0.097 \\
(0.123)\end{array}$ & $\begin{array}{c}0.023 \\
(0.168)\end{array}$ & $\begin{array}{l}-0.278 \\
(0.210)\end{array}$ & $\begin{array}{l}0.143^{*} \\
(0.058)\end{array}$ & $\begin{array}{c}0.114 \\
(0.067)\end{array}$ \\
\hline Family & $\begin{array}{l}0.288^{*} \\
(0.139)\end{array}$ & $\begin{array}{l}0.258^{*} \\
(0.128)\end{array}$ & $\begin{array}{c}0.390 \\
(0.207)\end{array}$ & $\begin{array}{c}0.423 \\
(0.368)\end{array}$ & $\begin{array}{c}0.105 \\
(0.178)\end{array}$ & $\begin{array}{l}-0.033 \\
(0.150)\end{array}$ & $\begin{array}{l}0.333^{* *} \\
(0.116)\end{array}$ & $\begin{array}{c}0.092 \\
(0.061)\end{array}$ & $\begin{array}{c}0.495^{* *} \\
(0.187)\end{array}$ & $\begin{array}{l}0.206 \\
(0.132)\end{array}$ & $\begin{array}{l}0.364^{*} \\
(0.166)\end{array}$ & $\begin{array}{l}-0.253 \\
(0.218)\end{array}$ & $\begin{array}{l}0.246 * * \\
(0.057)\end{array}$ & $\begin{array}{l}0.220 * * \\
(0.066)\end{array}$ \\
\hline All & $\begin{array}{c}0.179 \\
(0.134)\end{array}$ & $\begin{array}{c}0.225 \\
(0.118)\end{array}$ & $\begin{array}{c}0.318 \\
(0.210)\end{array}$ & $\begin{array}{c}0.293 \\
(0.309)\end{array}$ & $\begin{array}{l}-0.015 \\
(0.176)\end{array}$ & $\begin{array}{c}0.003 \\
(0.138)\end{array}$ & $\begin{array}{c}0.323^{* *} \\
(0.117)\end{array}$ & $\begin{array}{c}0.054 \\
(0.059)\end{array}$ & $\begin{array}{l}0.409 * \\
(0.193)\end{array}$ & $\begin{array}{c}0.127 \\
(0.123)\end{array}$ & $\begin{array}{c}0.071 \\
(0.165)\end{array}$ & $\begin{array}{c}-0.347 \\
(0.206)\end{array}$ & $\begin{array}{l}0.157^{* *} \\
(0.055)\end{array}$ & $\begin{array}{c}0.118 \\
(0.063)\end{array}$ \\
\hline Observations & 958 & 317 & 713 & 184 & 545 & 690 & 648 & 3,966 & 761 & 993 & 1,118 & 514 & 11,392 & 9,038 \\
\hline \multicolumn{15}{|c|}{ B. Education Measured by Years of Schooling } \\
\hline Baseline & $\begin{array}{l}0.0441 * \\
(0.0194)\end{array}$ & $\begin{array}{c}0.0341 \\
(0.0174)\end{array}$ & $\begin{array}{l}0.0224 * \\
(0.0112)\end{array}$ & $\begin{array}{l}-0.0085 \\
(0.0783)\end{array}$ & $\begin{array}{l}-0.0032 \\
(0.0163)\end{array}$ & $\begin{array}{l}-0.0040 \\
(0.0038)\end{array}$ & $\begin{array}{l}0.0247^{*} \\
(0.0100)\end{array}$ & $\begin{array}{l}0.0199 * * \\
(0.0076)\end{array}$ & $\begin{array}{c}0.0091 \\
(0.0063)\end{array}$ & $\begin{array}{l}0.0548 * \\
(0.0237)\end{array}$ & $\begin{array}{l}0.0329 * \\
(0.0146)\end{array}$ & $\begin{array}{c}0.0369 \\
(0.0221)\end{array}$ & $\begin{array}{l}0.0256 * * \\
(0.0061)\end{array}$ & $\begin{array}{l}0.0229 * * \\
(0.0071)\end{array}$ \\
\hline Income & $\begin{array}{c}0.0266 \\
(0.0199)\end{array}$ & $\begin{array}{c}0.0103 \\
(0.0164)\end{array}$ & $\begin{array}{c}0.0105 \\
(0.0115)\end{array}$ & $\begin{array}{l}-0.0387 \\
(0.0770)\end{array}$ & $\begin{array}{l}-0.0077 \\
(0.0164)\end{array}$ & $\begin{array}{c}-0.0041 \\
(0.0048)\end{array}$ & $\begin{array}{l}0.0247^{*} \\
(0.0100)\end{array}$ & $\begin{array}{c}0.0114 \\
(0.0075)\end{array}$ & $\begin{array}{c}0.0021 \\
(0.0062)\end{array}$ & $\begin{array}{c}0.0313 \\
(0.0220)\end{array}$ & $\begin{array}{l}-0.0008 \\
(0.0126)\end{array}$ & $\begin{array}{c}0.0294 \\
(0.0216)\end{array}$ & $\begin{array}{c}0.0135^{*} \\
(0.0053)\end{array}$ & $\begin{array}{c}0.0112 \\
(0.0062)\end{array}$ \\
\hline Family & $\begin{array}{l}0.0383^{*} \\
(0.0187)\end{array}$ & $\begin{array}{c}0.0101 \\
(0.0167)\end{array}$ & $\begin{array}{c}0.0344^{* *} \\
(0.0111)\end{array}$ & $\begin{array}{c}0.0053 \\
(0.0649)\end{array}$ & $\begin{array}{c}0.0098 \\
(0.0168)\end{array}$ & $\begin{array}{l}-0.0042 \\
(0.0037)\end{array}$ & $\begin{array}{l}0.0247^{*} \\
(0.0100)\end{array}$ & $\begin{array}{l}0.0247^{* *} \\
(0.0072)\end{array}$ & $\begin{array}{c}0.0146 * \\
(0.0066)\end{array}$ & $\begin{array}{l}0.0612 * * \\
(0.0235)\end{array}$ & $\begin{array}{l}0.0392 * * \\
(0.0144)\end{array}$ & $\begin{array}{c}0.0194 \\
(0.0231)\end{array}$ & $\begin{array}{l}0.0272^{* *} \\
(0.0060)\end{array}$ & $\begin{array}{l}0.0243^{* *} \\
(0.0070)\end{array}$ \\
\hline All & $\begin{array}{c}0.0227 \\
(0.0193)\end{array}$ & $\begin{array}{c}0.0060 \\
(0.0165)\end{array}$ & $\begin{array}{l}0.0268 * \\
(0.0124)\end{array}$ & $\begin{array}{l}-0.0183 \\
(0.0511)\end{array}$ & $\begin{array}{c}0.0009 \\
(0.0159)\end{array}$ & $\begin{array}{l}-0.0020 \\
(0.0050)\end{array}$ & $\begin{array}{l}0.0274 * * \\
(0.0104)\end{array}$ & $\begin{array}{c}0.0179 * \\
(0.0070)\end{array}$ & $\begin{array}{c}0.0086 \\
(0.0064)\end{array}$ & $\begin{array}{c}0.0319 \\
(0.0224)\end{array}$ & $\begin{array}{c}0.0172 \\
(0.0123)\end{array}$ & $\begin{array}{c}0.0128 \\
(0.0213)\end{array}$ & $\begin{array}{l}0.0169 * * \\
(0.0052)\end{array}$ & $\begin{array}{c}0.0139 * \\
(0.0060)\end{array}$ \\
\hline Observations & 956 & 317 & 713 & 184 & 545 & 690 & 648 & 3,942 & 761 & 993 & 1,116 & 514 & 11,364 & 9,010 \\
\hline
\end{tabular}

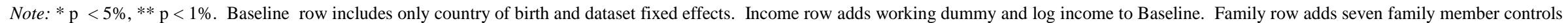
to Baseline. All row is full specification from Table 4. Trimmed remittances greater than twice annual income. Pooled sample weights post-stratified by education and country of birth. 
Figure 1

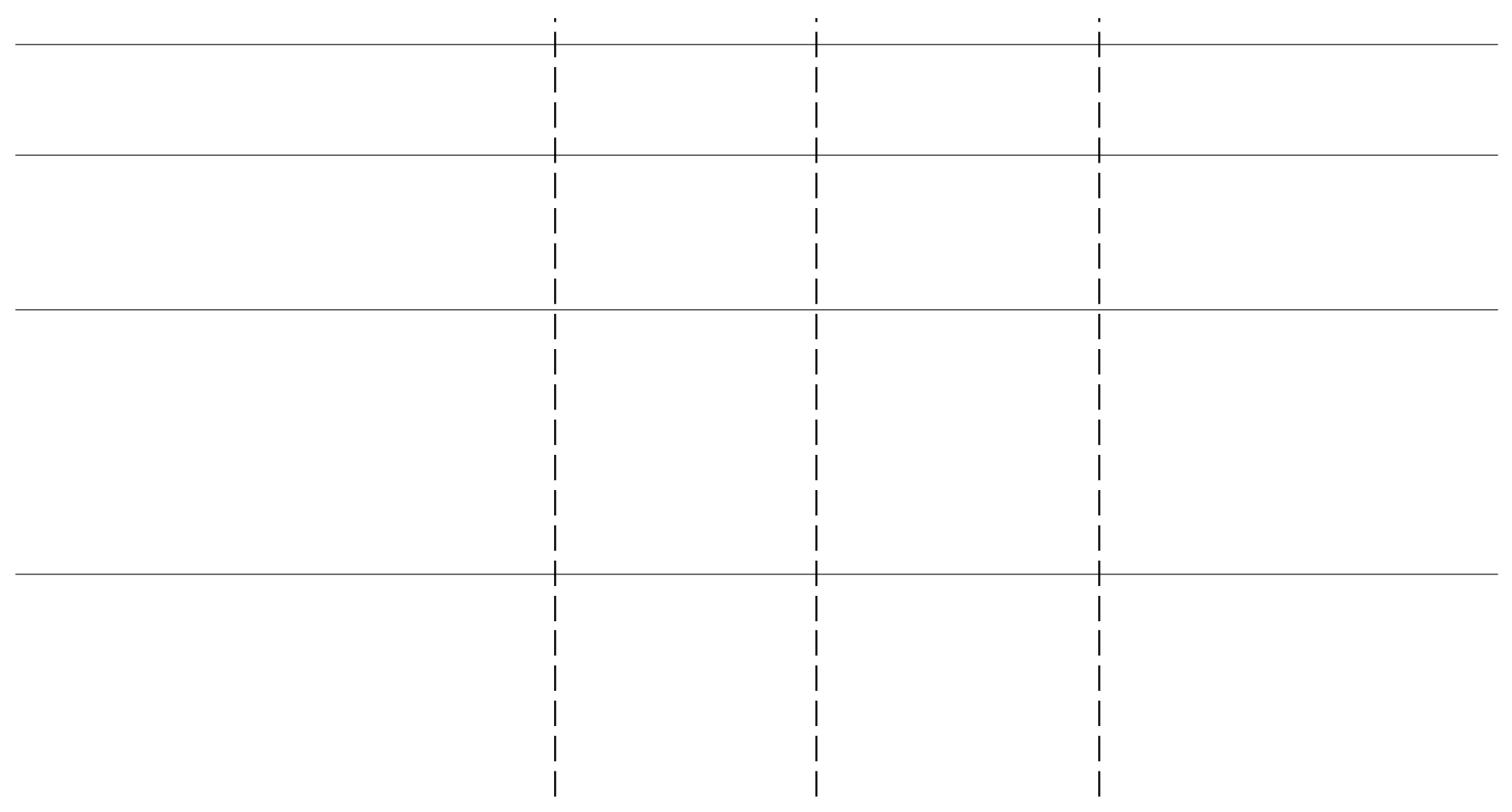

